\title{
SKILL BIASED FINANCIAL DEVELOPMENT: EDUCATION, WAGES AND OCCUPATIONS IN THE U.S. FINANCIAL SECTOR
}

\author{
Thomas Philippon \\ Ariell Reshef \\ Working Paper 13437 \\ http://www.nber.org/papers/w13437
NATIONAL BUREAU OF ECONOMIC RESEARCH
1050 Massachusetts Avenue
Cambridge, MA 02138
September 2007

We have benefited from discussions with Donghoon Lee, Holger Mueller, Tony Saunders, Bill Silber and Jeff Wurgler. The views expressed herein are those of the author(s) and do not necessarily reflect the views of the National Bureau of Economic Research.

(C) 2007 by Thomas Philippon and Ariell Reshef. All rights reserved. Short sections of text, not to exceed two paragraphs, may be quoted without explicit permission provided that full credit, including $\odot$ notice, is given to the source. 
Skill Biased Financial Development: Education, Wages and Occupations in the U.S. Financial Sector

Thomas Philippon and Ariell Reshef

NBER Working Paper No. 13437

September 2007

JEL No. G2,J21,J24,J3

\begin{abstract}
$\underline{\text { ABSTRACT }}$
Over the past 60 years, the U.S. financial sector has grown from 2.3\% to 7.7\% of GDP. While the growth in the share of value added has been fairly linear, it hides a dramatic change in the composition of skills and occupations. In the early 1980s, the financial sector started paying higher wages and hiring more skilled individuals than the rest of economy. These trends reflect a shift away from low-skill jobs and towards market-oriented activities within the sector. Our evidence suggests that technological and financial innovations both played a role in this transformation. We also document an increase in relative wages, controlling for education, which partly reflects an increase in unemployment risk: Finance jobs used to be safer than other jobs in the private sector, but this is not longer the case.
\end{abstract}

Thomas Philippon

NYU Stern School of Business

Department of Finance

44 West 4th Street, Suite 9-190

New York, NY 10012-1126

and NBER

tphilipp@stern.nyu.edu

Ariell Reshef

New York University

Department of Economics

19 W. 4th Street, 6FL

New York, NY 10012

ar825@nyu.edu 
The financial sector in the U.S. has grown steadily over the post-war period. In 1950, it accounted for $2.3 \%$ of U.S. GDP, and $2.8 \%$ of aggregate employee compensation. In 2005, both shares were $7.7 \%$. These steady increases, however, hide a deep structural break, that occurred in the early 1980s. Until then, and for more than three decades, the financial sector had grown by hiring more employees. From the early 1980s onward, the value added per employee increased much faster in the financial sector than in the rest of the economy, while the number of employees remained flat or even declined.

Understanding the growth of the financial sector, and the changing composition of its labor force, can shed light on several important economic issues. The first is the allocation of talent in the economy. It is well understood that entrepreneurial talent is a key input into the process leading to economic growth. Baumol (1990) argues that the allocation of talent across occupations is more readily influenced by institutions and economic incentives than the overall supply of talent. Economic growth requires the allocation of talent to socially productive activities. Murphy, Shleifer, and Vishny (1991) make a similar point, and also discuss the role of increasing returns to ability in determining the careers of talented individuals.

Both Baumol (1990) and Murphy, Shleifer, and Vishny (1991) argue that the flow of talented individuals into law and financial services might not be entirely desirable, because social returns might be higher in other occupations, even though private returns are not. Yet, there is little systematic evidence on changes in the flows of talent over time. Even if the potential for the diversion of talent exists, it does not matter if the diversion does not actually take place, or only on a small scale. Our paper sheds light on this issue.

Our work also contributes to the understanding of the much debated issue of skill biased technological change and income inequality. Katz and Murphy (1992) study the secular growth in the demand for more-educated workers from 1963 to 1987, while Autor, Katz, and Krueger (1998), Acemoglu (1998) and Card and Lemieux (2001), among others, discuss the role of technological improvements biased in favor of skilled workers. The finance industry has benefited greatly from innovation in computers and information technologies. We should therefore expect to see large changes in the relative productivities of its employees.

While computers are general purpose technologies, there have been a number of financial innovations since the 1960s. Silber (1983) reviews new financial products and practices be- 
tween 1970 and 1982. Miller (1986), reflecting upon the financial innovations that occurred from the mid 1960s to the mid 1980s, argues that the development of financial futures was the most significant one. Tufano (2004) argues that the more recent decades have witnessed equally important innovations. These innovations and the development of new markets probably changed the demand for skills in the financial sector. Moreover, they probably increased the span over which individuals can apply their skills, making the financial sector more attractive to highly talented individuals, as emphasized by Murphy, Shleifer, and Vishny (1991).

Finally, we contribute to the large literature on economic growth and structural change, with the well-known contributions of Stigler (1956), Kuznets (1957) and Baumol (1967). The rise in the finance industry is in some ways similar to the rise in other skill-intensive services, studied recently by Buera and Kaboski (2006), but the financial sector plays a particular role and needs to be analyzed separately. In a complete market, Arrow-Debreu economy, there would be no financial sector. The complete market is the benchmark for most economic applications. Studying the use of human capital in the financial sector might inform us about the most important departures from the complete market model.

In this paper, we provide evidence on the transformation of the financial industry by looking at the occupations, education and wages of its workforce. Was there a general increase in the average education of the workforce entering the industry? Did some low skill occupations disappear? Which occupations expanded? To answer these and other questions, we turn to the Current Population Survey. Although this survey has been extensively used to study the U.S. labor market at large, to the best of our best knowledge it has not been utilized to study the financial sector in particular.

Our analysis uses a long time series and a representative sample of U.S. population. This sample, however, is not appropriate for the study of very high incomes, which is the focus of recent work by Kaplan and Rauh (2007).

We find that until the late 1970s, workers in the financial sector were only slightly more educated and received slightly higher wages than in the rest of the economy. Since the early 1980s, however, the financial sector has been hiring more and more skilled individuals, at a higher rate than the rest of the private sector. The increase in the skill intensity of the finance labor force reflects both a composition shift away from the Banking industry and 
towards investment banks, mutual, pension and private equity funds, which are relatively more skill intensive, and an increase in skill intensity within some industries. Along with the rise in skills, we document an increase in the wages paid to workers in the financial sector, which is partly due to a relative increase in unemployment risk. Finally, we analyze the changes in the set of tasks performed by workers in the financial sector.

Section 1 describes the growth of the financial sector, as well as three industries within the industry. Section 2 considers the role of education in explaining the rise of wages paid to employees in the financial sector. Section 3 studies the evolution of residual wages, controlling for education, and the role of unemployment risk. Section 4 concludes. A detailed description of the data can be found in the appendix.

\section{The growth of the financial sector}

In this section, we present broad trends for the U.S. financial sector over the post-war period. We consider first the industry as a whole, using data from the Annual Industry Accounts of the United States, and then three industries within the industry, using the March supplement of the Current Population Survey. The data are described in details in the appendix.

\subsection{Trends for the sector}

We start from the Annual Industry Accounts of the United States, published by the Bureau of Economic Analysis. We consider three measures of the size of an industry: value added, compensation of employees, and employment. Value added is the contribution of the industry's labor and capital to the overall gross domestic product (GDP) of the country. We also compute the compensation share. Compensation includes wage and salary accruals, as well as supplements to wages and salaries. The compensation share and the value added share of an industry can differ if the share of labor in the value added of the industry is not equal to the labor share in the rest of the economy. For employment, we use the series Full-Time and Part-Time Employees (FTPT) because it is consistently defined over the whole postwar period. This measure simply counts the number of employees in the industry without adjusting for the number of hours worked. ${ }^{1}$

\footnotetext{
${ }^{1}$ The full-time equivalent series (FTE) is available only from 1998 onward.
} 
Figure 1 shows that, in terms of valued added and compensation of employees, the share of the financial sector has grown fairly linearly over the post-war period. However, the pattern for the employment share is markedly different. The employment share of the financial sector grows just like the value-added share until the early 1980s, but it then flattens out and even declines somewhat after 1987.

The growth of the financial sector can therefore be decomposed into two distinct periods:

- From 1947 to 1977, the share of value added of the financial sector increased from $2.32 \%$ to $4.55 \%$, an increase of 2.23 percentage points over 30 years. The share in the compensation of employees increases from $2.72 \%$ to $4.36 \%$. During this period, the financial sector grows mostly by hiring more employees. The share of employment increases from $2.39 \%$ to $3.86 \%$, and the compensation per employee grows like in the rest of the economy.

- From the 1980s onward, the financial sector grows by increasing the value added and compensation of its employees faster than in the rest of the economy. The employment share remains roughly constant, increasing to a maximum of $4.64 \%$ in 1987, and then falls to $4.32 \%$ in the early 2000 s. The value added share increases from $4.55 \%$ in 1977 to $7.69 \%$ in 2005 , an increase of 3.14 percentage points over 28 years, faster than in the previous period.

\subsection{Trends for industries}

We now turn to the March supplement of the Current Population Survey. The Current Population Survey (CPS) is a monthly survey of over 50,000 households conducted by the Bureau of the Census for the Bureau of Labor Statistics. In this section, and in the rest of the paper, we focus on the private sector: we exclude all government employees, as well as employees of the United States Postal Services. There are two reasons for doing so. The first is to check that the trends identified earlier also hold for the share of finance within the private sector. The second, more important reason is that the private sector is a better control group than the whole economy, in particular when we think about unemployment risk.

In the previous section, we treated financial sector as one large homogenous sector. One 
might wonder, however, whether the trends that we have described are the same in all industries. We define three industries within the financial sector: "Banking and Saving", "Insurance" and "Other Finance Industries". Banks, thrift and saving institutions are included in "Banking and Saving". Securities, commodities, funds, trusts, and other financial establishments, as well as investment banks are all included in "Other Finance Industries". The top panel of Table 1 explains the classification, and Table 2 contains the number of observations and the shares of employment of each industry on a full-time equivalent basis, computed with the Census weighting scheme to obtain a sample representative of the U.S. economy. Note that these are shares in the private sector, and therefore they add up to more than the share presented in Figure 1. The trends, however, are consistent with those from the Industry Accounts. In the CPS, the employment share of finance increases until the early 1980s and remains constant afterwards. The wage-bill share increases linearly throughout the 1970-2005 period, just like the value added share described above.

The left panel of Figure 2 shows the size of each industry in terms of hours worked. The share of the Insurance sector is remarkably stable, at $2 \%$ of total hours worked. The share of Banking increases from $2 \%$ in 1970 to $3 \%$ in 1988, and then decreases to $2.75 \%$ in 2006. By contrast, the share of Other Finance Industries was constant until 1980 at around $0.3 \%$ before increasing to $0.9 \%$ in 2006. The right panel of Figure 2 shows the size of each industry in terms of its wage bill. Interestingly, the wage-bill share of Other Finance Industries increased by more than twice as much as its share of hours worked. There are smaller differences between the (increase in) wage-bill and (flat) hour share in the other two industries. The financial sector accounted for $4.875 \%$ of private labor income in 1967 and $8.127 \%$ in 2005, an increase of 3.252 percentage points. Other Finance Industries increased by 1.68 percentage points, from $0.62 \%$ to $2.3 \%$, so it accounts for slightly more than half of the overall increase of the industry.

\section{Result 1}

Over the post war period, the financial sector grew first by hiring more employees, and later by increasing the value added of its employees. Wages in finance increased much faster than in the rest of the economy from the late 1970s onward. The composition of the sector has shifted away from Banking and towards Other Finance Industries. 
An increase in the relative wage can reflect various economic forces. In the short run, because of search costs and industry specific human capital, the supply of labor is not perfectly elastic across industries. Thus, an increase in demand or in productivity can lead to an increase in relative wages, holding constant the composition of the labor force. In the long run, however, the relative labor supplies adjust and differences in wages reflect differences in human capital and in the disutility from work in different occupations. Our next step is therefore to investigate the education of employees in the finance industry.

\section{Education of the workforce}

In this section, we investigate whether the evidence in Figures 1 and 2 reflect a shift in the composition of the labor force of the financial sector around 1980. Our CPS data cover the period 1967-2005. Over this period, the average education of the U.S. workforce has increased substantially. We investigate whether the improvement in education has been relatively faster or slower in the financial sector.

\subsection{Wages and education}

Given that value added per employee started to increase relatively faster in the financial sector after 1980, it is natural to study the skill composition of the labor force. To do so, we break down hours worked between employees with less than a college degree and employees with at least a college degree. Let $h_{i, s, t}$ be hours worked by employee $i$ in sector $s$ at time $t$, and let $e_{i, t}$ be a dummy variable for having at least a college degree. We define the college graduate share of hours worked in sector $s$ at time $t$ as:

$$
x_{s, t}=\frac{\sum_{i} h_{i, s, t} \omega_{i, t} e_{i, t}}{\sum_{i} h_{i, s, t} \omega_{i, t}},
$$

where $\omega_{i s t}$ is the CPS sampling weight for that observation. The relative education of the workforce of the financial sector is defined as the college graduate hour-share in Finance and Insurance $(s \equiv$ fin) minus the college graduate hour-share in the rest of the private sector $(s \equiv$ rop $): x_{f i n, t}-x_{r o p, t}$. We also construct the average hourly wage in each sector $w_{s, t}$, and we define the relative wage as the percentage difference in average hourly wages: $\left(w_{f i n, t}-w_{\text {rop }, t}\right) / w_{\text {rop }, t}{ }^{2}$ Figure 3 shows the evolution of the relative wage and the relative

\footnotetext{
${ }^{2}$ Average wages are weighted averages, using CPS weights.
} 
education over time. The two series display some striking similarities. Both are flat until 1980 and rise linearly afterwards, which suggests that part of the observed increase in relative wages comes from a relative increase in the skill composition of the labor force. Until 1980, wages are $12.5 \%$ higher and the hour-share of college graduates is 2.5 percentage points higher in finance than in the rest of the private sector. By 2005, wages are more than $40 \%$ higher and the hour-share of college graduates is 17.5 percentage points higher.

\section{Result 2}

The education of employees in the financial sector increased faster than in the rest of the economy after 1980.

Does education account for the entire increase in relative wages? If wages are equalized across sectors for a given level of education, the percentage difference in average hourly wages should be equal to $\pi_{t}\left(x_{f i n, t}-x_{r o p, t}\right) /\left(1+\pi_{t} x_{r o p, t}\right)$, where $\pi_{t}$ is the college premium at time $t$, defined as the percentage difference in the hourly wages of workers with and without a college degree. The hour-share of college graduates increased from $13 \%$ to $30 \%$ in the private sector between 1967 and 2005, and from $18 \%$ to $47.5 \%$ in the financial sector. The college premium - the percent difference between the wages of college graduate and those without a college degree - is around $55 \%$ in the 1970s and reaches $94 \%$ by the end of our sample. ${ }^{3}$

Given the college premium and the differences in the hour shares of college graduates, we would have expected finance wages to be $2.6 \%$ higher than in the rest of the economy in 1970, while in fact they were $12.5 \%$ higher. By 2005, we would have predicted a $12.83 \%$ difference in wages, compared to the observed $40 \%$. The discrepancy comes from the fact that employees of the financial sector earn more than employees in other sectors with similar levels of education, and that the gap has increased over time. We address this issue in section 3.

\subsection{Skill intensity}

We use a simple model of the demand for skill to organize our discussion of skill intensities. Suppose that there are two skill levels, $h$ and $l$, and that the production function of sector

\footnotetext{
${ }^{3}$ The increase in the college premium is well known in the literature. See Katz and Murphy (1992) for instance.
} 
$s$ is:

$$
y_{s}=f\left(\mu_{s}^{1 / \sigma} h^{1-1 / \sigma}+\left(1-\mu_{s}\right)^{1 / \sigma} l^{1-1 / \sigma} ; X_{s}\right)
$$

where $X_{s}$ is a vector of industry characteristics, and $h$ and $l$ are hours worked by high education and low education workers, respectively. This production function has a constant elasticity of substitution between high and low skill labor, $\sigma$. Many models of macroeconomic growth use production functions with constant values for $\sigma$. Let $w_{h}$ and $w_{l}$ be the hourly wages for high and low education workers. Cost minimization of the wage bill for any level of output in (2) implies that the relative demand for high skill labor must satisfy: ${ }^{4}$

$$
\frac{h_{s}}{l_{s}}=\frac{\mu_{s}}{1-\mu_{s}}\left(\frac{w_{h}}{w_{l}}\right)^{-\sigma}
$$

In the benchmark case, where $\sigma$ and $w_{l} / w_{h}$ are the same across sectors, the relative skill intensity $h_{s} / l_{s}$ depends only on the relative parameters $\mu_{s}$ across different industries. ${ }^{5}$ In particular, using (3) to compare finance versus the rest of the economy leads to:

$$
\frac{h_{\text {fin }} / l_{\text {fin }}}{h_{\text {rop }} / l_{\text {rop }}}=\frac{\mu_{\text {fin }}}{1-\mu_{\text {fin }}} \frac{1-\mu_{\text {rop }}}{\mu_{\text {rop }}} .
$$

Figure 4 focuses on employees with a least a college degree. The left panel shows the share of hours worked by employees with at least a college degree in each industry, computed according to equation (1). For the total private sector, it increased from $13.2 \%$ in 1968 to $30.6 \%$ in 2006, with a sample average of $23 \%$. This share, however, varies a lot across sectors. The sample average is $53.8 \%$ for Other Finance Industries, $32 \%$ in Insurance companies, and $26.3 \%$ in Banking. The trend increase in Insurance is the same as in the rest of the private sector, but the trends are steeper in Banking and Other Finance Industries. The share of college graduates in Banking was roughly the same as in the rest of the private sector in the early 1970s (even slightly lower), but 10 percentage points higher in 2005.

The right panel of Figure 4 shows the evolution of the left-hand side of equation (4) over time, using hours worked by college graduates as a measure of $h$. The series are normalized to have a mean of one over the first five years, 1967 to 1971. Interestingly, the

\footnotetext{
${ }^{4}$ These relationships do not require perfect competition in the market for goods and services, since they follow from cost minimization, and not from profit maximization. They do require that firms take wages as given, however.

${ }^{5}$ Although wages grow faster in the financial sector, the relative wage of college graduates was not markedly different from the rest of the private sector. See Figure 9.
} 
relative skill intensity of Insurance has remained roughly constant throughout the sample period, consistent with the benchmark model and balanced growth. On the other hand, the relative skill intensity in Banking and in Other Finance Industries has increased sharply. The Banking sector was slightly less skill intensive than the rest of the economy in the early 1970s, but it became significantly more skill intensive over the 1980s. The Other Finance Industries sector was already skill intensive and has become more so over time.

\section{Result 3}

The relative skill intensity of the Insurance industry has remained approximately constant. In contrast, Banking and Other Finance Industries have become more skill-biased than the rest of the economy after 1980.

So far, we have documented an increase in the skill intensity of the financial sector relative to the rest of the economy, and a change in the allocation of the workforce within the financial sector away from Banking and towards Other Finance Industries. These trends presumably reflect changes in the set of tasks performed by workers in the financial sector, a topic that we now discuss.

\subsection{Occupations}

Our classification of occupations attempts to group employees according to the tasks they perform, irrespective of the industry in which they work. For instance, we classify all employees trading securities as traders, no matter whether they work in Banking, Insurance or Other Finance Industries. We do the same for managers and for administrative workers. Unfortunately, it is hard to find consistent definitions of occupations over time. The appendix explains in details what we did, the constraints we faced and the reasons for our choices. At the end of the day, we use six occupations, presented in the bottom panel of Table 1. Table 3 contains the number of observations for each occupation and each year, and the shares of each occupation in the total employment of the Finance and Insurance sector.

Figure 5 shows the evolution of the employment shares of four occupations: The two largest on the left panel, and the two fastest growing on the right panel. The fraction of clerks and workers employed in administrative tasks has declined dramatically over time. 
This is true in all industries, and it is particularly important in Banking. The decrease in the share of clerks explains much of the evolution of average wages in Banking after 1980. "Securities and Financial Asset Sales" and "Computer and Mathematics" are the fastest growing occupations. ${ }^{6}$ It is clear that the financial sector has become more trading-intensive and more computer-intensive over time.

\section{Result 4}

Much of the skill bias in Banking reflects the decline of bank tellers and other administrative occupations. The fastest growing occupations in finance are related to the trading of financial assets, and the use of computers and mathematics.

\subsection{Technological or financial innovations?}

Autor, Levy, and Murnane (2002) sort jobs and tasks along two dimensions: manual or cognitive, routine or non-routine. Computers can perform routine tasks and are therefore substitutes for labor employed in routine jobs. Computers are complements to non-routine tasks, especially cognitive ones, and they are neither complements nor substitutes to manual non-routine tasks. As a result, employees in abstract or analytical tasks become more productive, the demand for routine jobs decreases, while manual jobs are less affected.

The evolutions of the tasks performed by the financial sector provide support for the idea that advances in information technology, and in particular the decrease in the price of computing power, have considerably decreased the demand for routine jobs and increased the productivity of non-routine abstract jobs.

The relative stability of Insurance, however, suggests that financial innovations might also have played a role. Insurance was already a skill intensive industry in 1980, yet its evolution does not suggest a strong skill bias afterwards. Moreover, one might think that improvements in computers by themselves affected the insurance sector as much as the other financial sectors.

It seems likely that financial innovations also played an important role. Indeed, among the 38 new financial products and practices introduced between 1970 and 1982 listed in

\footnotetext{
${ }^{6}$ One should keep in mind that, as shown in Table 2, there are few observations in these occupations at the beginning of the sample, which explains the initial volatility of the series.
} 
Silber (1983), only 2 or 3 are related to Insurance. These innovations had a larger impact on Other Finance Industries than on the Insurance industry. Many of these innovations are market-oriented, which explains the nature of the fastest growing occupations in Figure 5. This is also consistent with the argument in Miller (1986) on the importance of financial futures markets.

\section{Wage premia in the financial sector}

To what extent can education account for the change in relative wages that we have documented? In this section, we document that even controlling for education, finance wages have increased faster than in the rest of the economy, and then we show that this might partly reflect an increase in unemployment risk. To make the discussion more concrete, we start by considering the striking example of engineers.

\subsection{Financiers and engineers}

In this section, we focus on a particular comparison, that between engineers and financiers with similar levels of education. Figure 6 shows the evolution of the average annual wages of employees in the Finance and Insurance sector with a college degree or more, and of engineers employed in the private sector (but not in Finance and Insurance). The wages are in constant 2000 prices. The left panel uses individuals with exactly a college degree, and the right panel uses employees with a post-graduate degree. In both cases, the relative wage of finance employees was constant until the 1980s, and then started to increase faster than the wage of engineers with the same level of education. The picture is particularly striking for post-graduates, a category that includes MBAs and $\mathrm{PhD}$ graduates.

Moreover, the CPS underestimates the income of individuals who earn very high salaries, due to top-coding of income. Therefore, the wages that we report may not be accurate for certain occupations, Securities and Financial Asset Sales in particular. In our sample, the percent of top-coded observations in the private sector is around $1 \%$, but it is around $2 \%$ in Banking, 2.5\% in Insurance and up to $13 \%$ in Other Finance Industries. We have tried to correct the induced biases, as explained in the appendix, but it is not possible to remove them entirely. See Kaplan and Rauh (2007) for a detailed analysis of the highest incomes inside and outside finance. 


\subsection{Wage regressions}

We have seen that the wages of employees in the financial sector have increased relative to the rest of the private sector. This increase has been accompanied by an increase in the share of college graduates working in the financial sector. The first question we seek to answer is whether the change in the composition of the labor force, in particular its education, can account for all of the observed increase in wages.

To answer this first question, we run a series of cross-sectional regressions on subsamples of five years. ${ }^{7}$ Pooling the data ensures that we have enough observations in each cell. We restrict our attention to full time employees of the private sector, i.e., employees who work at least 40 weeks a year, and at least 35 hours a week. ${ }^{8}$ For each subsample $\tau \in\{[1967,1970], \ldots[2001,2005]\}$, we run the following regression:

$$
\log \left(w_{i t}\right)=\alpha_{t, \tau}+\beta_{\tau} \cdot X_{i, t}+\gamma_{\tau} \cdot e d u_{i, t}+\phi_{\tau} 1_{i t}^{\phi}+u_{i t}
$$

where $t \in \tau$. In equation (5), $w_{i t}$ are the annual wage earnings of individual $i$ in year $t, X_{i t}$ are individual characteristics of individual $i$ at time $t$ (race, sex, marital status, urban residence, potential experience and its square), and $e d u_{i t}$ is a vector of dummies for education groups: 12 years of education, 13 to 15 years, 16 to 17 years, and 18 years or more. The variable $1_{i t}^{\phi}$ is a dummy, equal to one if individual $i$ works in the financial sector in year $t$. Within each period we also control for year effects $\alpha_{t, \tau}$. We allow the vector of coefficients $\gamma_{\tau}$ to vary over periods in order to capture changes in the returns to education common to all sectors in the economy. The coefficient $\phi_{\tau}$ measures the extent to which every finance employee receives a higher wage, controlling for all other things. It captures compensating wage differentials or unobserved heterogeneity.

Table 4 displays the results of the regressions (5). The most striking feature of the data is the increase in the returns to education, especially for high education. Mincer (1997), Lemieux (2006) and Deschênes (2006) show that log wages have become an increasingly convex function of the years of education since the 1970s, and Autor, Katz, and Kearney (2006) argue that the U.S. labor market has become more polarized since 1980. Indeed, one can see in Table 3 that the gap between high-school graduates and college-educated workers

\footnotetext{
${ }^{7}$ The first regression uses the first four years of data, from 1967 to 1970.

${ }^{8}$ Our sample excludes individuals that earned less than $80 \%$ of the federal minimum hourly wage.
} 
has increased dramatically, while the gap between high-school graduates and dropouts has increased only moderately. Controlling for education is important if one wants to understand the evolution of the wages of workers in the financial sector.

Figure 7 plots the evolution of $\phi_{\tau}$ from two specifications of equation (5), one where we exclude education (not reported here) and one where we include education, which corresponds to the first row of Table 4. The drop from one line to the other shows that education accounts for six to eight percentage points of the difference in log wages. However, even controlling for education, we find that individuals working in the Finance and Insurance sector earn more than individuals working in the Rest of the Private Sector. The 'finance premium' was small, around $3.4 \%$ until the mid-seventies. It started to grow in the late 1970 s, to reach $20 \%$ in the early 2000 s. To better understand the 'finance premium', we decompose it into three premia, one for each of our industries. Figure 8 shows that the wage differentials have increased in all three industries. In Banking, there is no wage differential in the early 1980s. The wage differential is much larger in Other Finance Industries, which is the more skill intensive sector. Moreover, in this industry it increases the most, by more than 20 percentage points. However, since we control for observed skill, this is indeed a premium for working in the sector.

Our previous specification implicitly assumed that wage differentials were the same for all education groups. We now relax this assumption and run the following regression:

$$
\log \left(w_{i t}\right)=\alpha_{t, \tau}+\beta_{\tau} \cdot X_{i, t}+\gamma_{\tau} \cdot e d u_{i, t}+\left(\phi_{\tau}+\gamma_{\tau}^{\phi} \cdot e d u_{i, t}\right) 1_{i t}^{\phi}+u_{i t}
$$

The vector of coefficients $\gamma_{\tau}^{\phi}$ measures the additional return to education in the financial sector. Table 5 displays the results of the regressions and Figure 9 plots the evolution of the wage earnings of college and high school graduates inside and outside finance. Within each education group, the wage differential is small in the 1970s and starts to increase in the early 1980s. The wage regressions therefore confirm that a specific transformation took place in the financial sector in the late 1970s and early 1980s - one that affected all education groups and all industries within finance. In addition, the results show that the college premium - the relative wage of college graduates to high school graduates - is roughly the same in finance as in the rest of the private sector.

\section{Result 5}


Controlling for the observed characteristics of employees, the relative wage in finance started to increase in the late 1970s. A similar pattern emerges within each industry and within each education group.

\subsection{Wage differentials and unemployment risk}

That two individual with the same education and observable characteristics earn such different income can be explained in one of three ways: compensating differentials, employment and wage risk, and unobserved heterogeneity. According to the first candidate explanation, finance jobs are relatively less attractive than non-finance jobs, and, in equilibrium, this is reflected in the relative wages. Compensating differentials are certainly important, and they can account for a fraction of the average differences that we observe. However, they do not strike us as a plausible explanation for the increase in the relative wages paid in the financial sector, because it is hardly sensible to argue that finance jobs are less interesting today than they were 30 years ago, especially relative to the rest of the private sector.

Another, and in our view more plausible, explanation for the trends in relative compensation, is a relative increase in labor income risk in the financial sector. If finance workers are more likely to loose their jobs, or if their wages are more volatile, they would have to be compensated for this extra risk. To test this explanation, we fit two regressions. Let $\lambda_{i t}$ be a dummy for being employed at time $t$. First, we run a logit regression on the likelihood of becoming unemployed:

$$
\operatorname{Pr}\left(\lambda_{i t+1}=0 \mid \lambda_{i t}=1\right)=f\left(1_{i t}^{\phi} ; w_{i t} ; e d u_{i, t} ; X_{i, t}\right)
$$

where $f$ is the logistic function.

The estimation of equation (6) requires a longitudinal dimension. Therefore we use the Matched CPS, which allows us to potentially observe each individual in the CPS twice, in two consecutive years. See the appendix for a complete description of the methodology involved in matching observations on individuals from consecutive surveys.

We use a broad definition for unemployment. It includes not only the individuals who are not employed and are looking for a job for the entire year, but also those that worked part-year and were actively looking for a new job in some of the weeks not worked. ${ }^{9}$ Thus,

\footnotetext{
${ }^{9}$ See appendix for a more detailed definition.
} 
to be in the sample at time $t$, an individual must be in the labor force, and employed in the private sector. At time $t+1$, the individual must be in the labor force (in the private or public sectors), either employed or not. On average, over the whole sample, $6.91 \%$ of individuals experience a transition from employment to unemployment. Individuals in the financial sector are less likely to loose their jobs: only $4.39 \%$ make the transition. The relative stability of finance jobs has decreased over time, however, as one can see in Table 6, which reports our estimates for equation (6). As expected, full time, married, experienced workers, and workers with a higher level of education, are less likely to become unemployed.

Figure 10 shows the evolution of unemployment risk in the financial sector relative to the private sector. The probability of becoming unemployed is evaluated for the average worker, i.e., it is evaluated at the means of all other variables. From the late 1970s to the early 1990s, the stability of jobs in the financial sector has converged to the average for the rest of the private sector. This convergence started in the early 1980s, which coincides with the timing of the increase in relative wages in finance, as shown in Figure 2.

When we estimate equation (6) with separate dummies for the three industries, we find clear trends in Banking and Insurance. In Other Finance Industries we do not observe enough transitions to draw reliable conclusions. We have also estimated an equation with wage risk, measured either by the volatility of the log wage, or by the probability of a drop of more than $10 \%$, on the left hand side. We did not find any evidence that wage risk is higher in the financial sector, or that the relative risk has changed over time.

An important concern with our controls for education is that it might not capture important heterogeneity among individuals with the same number of years of schooling. A better way to capture this heterogeneity is to control for the current wage, rather than education. To do so, we construct three wage groups with cutoffs at the 34th and 67th percentiles of the overall wage distribution in a given year. Note that the cutoffs correspond to the distribution of wages in the entire private sector, not the financial sector, because the correct experiment is to compare individuals with the same wages inside and outside the financial sector. Table 7 reports the results of the regression. Figure 11 shows the evolution of the relative unemployment risk of jobs in the financial sector, broken down into these three wage groups. Once again, we observe a clear upward trend in all groups. 


\section{Result 6}

Unemployment risk was lower in the financial sector than in the rest of the private sector until 1980. It increased in relative terms over the 1980 s and early 1990 s.

\section{A simple calibration}

Based on the evidence presented so far, we can propose a first interpretation of the data. Regarding the level of compensation, a constant compensating differential appears to be required, since even in the more recent years, the unemployment risk in the finance industry is not higher than in the rest of the economy. It has merely converged to the same level. The increase in the relative unemployment risk in the financial sector can however account for some of the increase in relative wages. Ruhm (1991) finds that layoffs lead to temporary unemployment and long lasting decreases in earnings: "Displaced workers were out of work eight weeks more than their observably similar counterparts in the year of the separation, four additional weeks in period $t+1$, and two extra weeks at $t+2$. By year $t+3$ they were jobless only 1.5 weeks more than the peer group, and the $t+4$ increase was just six days." By contrast, "almost none of the $t+1$ wage reduction dissipated with time. The earnings gap remained at 13.8 percent and 13.7 percent, respectively, in years $t+3$ and $t+4$."

A complete study of the effects of unemployment risk on the level of compensation that is needed to keep workers indifferent between different jobs is clearly beyond the scope of this paper. Nonetheless, we think it is useful to provide some simple benchmark calculations. We do so in the simplest framework possible and we assume that labor income is the only source of risk and that the utility function has constant relative risk aversion. We set the personal discount rate and the market rate both equal to $3 \%$ per year. We assume that workers live and work for 40 years, and that the labor income process, $y_{t}$, is given by

$$
y_{t+1}=\left\{\begin{array}{c}
1.02 y_{t} \text { with probability } 1-p \\
0.86 y_{t} \text { with probability } p
\end{array}\right\} \text {, and } y_{1} \text { given. }
$$

The increase of $2 \%$ captures the normal increase in real labor income. The drop by $14 \%$ captures the income loss from displacement documented by Ruhm (1991). This process implies that shocks are permanent, which makes the effect of unemployment risk more important, so we are likely to obtain an upper bound for the impact on the relative wages.

We perform the following experiment. First, we set $p=4.41 \%$ and $y_{1}=1$, we solve and simulate the model with a coefficient of relative risk aversion equals to 2 . We then 
increase the unemployment risk to $p=6.91 \%$. This increase of 2.5 points corresponds to the increase in relative unemployment risk that we have documented earlier. In order to keep workers indifferent, the new starting wage should be $y_{1}=1.084$, an increase of $8.4 \%$. If we lower the calibrated risk aversion to 1 , the required increase in wages is $7.8 \%$. If we increase risk aversion to 3 , the required increase in wages is $9 \%$. Recall that the premium paid to finance employees has increased by 16.6 points, from $3.4 \%$ to $20 \%$. Thus, it appears that the increase in unemployment risk could account for half of the increase in relative wages.

\section{Conclusion}

Until the late 1970s, workers in the financial sector were only slightly more educated and received slightly higher wages than in the rest of the economy. Since the early 1980s, however, the financial sector has been hiring more and more skilled individuals. There has been a composition shift away from Banking and towards relatively more skill intensive industries. In addition, there has been an increase in skill intensity within Banking and within Other Finance Industries.

Our results suggests two sources of skill bias: computers and market-related financial innovations. First, there is clear evidence that jobs involving routine tasks have tended to disappear, probably because of improvement in computers and information technologies. This is especially true in Banking, where the trend may have been reinforced by deregulation and consolidation. The relative stability of Insurance, however, as well as the fact that the fastest growing tasks involve the trading of financial assets suggests that innovations in financial markets also played an important role.

Controlling for education and observable characteristics, we find that employees of the financial sector earned 3 to $4 \%$ more than employees in the rest of the private sector during the 1970s. At that time, however, they also enjoyed substantially lower unemployment risk. After 1980, the unemployment risk in the financial sector started to catch up with unemployment risk in the rest of the private sector. Over the same period, the finance wage premium (controlling for education and observable characteristics) increased to $20 \%$. A simple calibration suggests that the increase in relative unemployment risk could account 
for one half of the increase in the finance wage premium. The remaining half probably reflects unobserved heterogeneity in the labor force.

Overall, the share of talented individuals hired by the financial sector has increased very significantly over the past three decades. This finding raises several questions for future research. First, does the increase in skilled labor in the financial sector lead to more innovations in this sector? Second, how do financial innovations affect the rest of the economy? Finally, what are the welfare consequences of the shift in the allocation of talent ${ }^{10}$

\footnotetext{
${ }^{10}$ Philippon (2007) discusses the optimal allocation of talent in a model with credit constraints and industrial innovations, but no financial innovations.
} 


\section{Appendix}

\section{A Description of the data}

\section{A.1 Annual industrial accounts}

We obtain data on employment and value added at the industry level from the Bureau of Economic Analysis (BEA). Value added, the contribution of each industry's labor and capital to the overall gross domestic product (GDP), is equal to an industry's gross output (Sales or receipts and other operating income, commodity taxes, and inventory change) minus its intermediate inputs (consumption of goods and services purchased from other industries or imported). Current-dollar value added by industry is calculated as the sum of disbursements to its labor and capital which are derived from the components of gross domestic income.

Employment could be defined in a number of ways: all employees, full-time equivalent, or total hours worked. There is, however a compatibility issue around 1997, when the BEA changed its industry classification from SIC to NAICS. As a result, only the series for the number of 'full time and part time employees' (FTPT) is available consistently, and this is the one that we use. The 1948-97 full-time and part-time employees was released in October 2006, by the Industry Economic Accounts, Bureau of Economic Analysis (BEA), U.S. Department of Commerce. Because this series is based on the current NAICS classification, it is possible to link the 1948-1997 and 1998-2005 samples.

\section{A.2 The Current Population Survey}

Our data on individuals comes from the March supplement of the Current Population Survey (Annual Social and Economic Study) from survey years 1968-2006, which pertain to 1967-2005 actual years. A CPS year refers to data of the preceding year, i.e. March CPS 2006 documents annual data from calendar year 2005. We therefore adopt the following taxonomy: We call "year" the actual year that the survey pertains to, while a CPS year is denoted as "survey year". The Current Population Survey (CPS) is a monthly survey of about 50,000 households conducted by the Bureau of the Census for the Bureau of Labor Statistics. ${ }^{11}$ Currently, there are more than 65,000 participating households. The sample is selected to represent the civilian non-institutional U.S. population. The CPS includes data on employment, unemployment, earnings, hours of work, and other demographic characteristics including age, sex, race, marital status, and educational attainment. Also available are data on occupation, industry, and class of worker. We choose to use only one particular month survey, the March supplement, for two reasons. First, this supplement contains more demographic details, in particular on work experience and income sources and amounts. Since 1976, the survey has also been supplemented with a sample of Hispanic households (about 2,500 interviewed). Second, it has been extensively used in the empirical labor and macro-labor literature, which lends to the comparability of our results. Let us now define the groups that we use in our empirical analysis. We restrict attention to individuals who are in the labor force, of at least 15 years of age.

\section{Industry Classification}

We define three industries within the private sector: "Banking and Saving", "Other Finance Industries", and "Insurance". To define the private sector, we exclude all government employees, as well as employees of the United States Postal Services. Banks, thrift and saving institutions are included in "Banking and Saving". Securities, commodities, funds,

\footnotetext{
${ }^{11}$ We obtained the data from Unicon Research, http://www.unicon.com/
} 
trusts, and other financial investments as well as investment banks are all included in "Other Finance Industries". Table 2 shows the number of observations of employees surveyed from the three financial industries and from the rest of the private sector from 1968 to 2006. Table 2 also shows the shares of employment, computed with the Census weighting scheme to obtain a sample representative of the U.S. economy. These sectors are consistently identified, without any "jumps" or "drops" in their shares of total employment, despite changes in industrial classifications in the CPS in our sample, which occur following each decennial census. The major industrial re-classifications occurred in survey year 1983, from the Census 1970 system to the 1980 system; and in survey year 2003, from the Census 1990 system to the 2000 system. Of these two re-classifications, the latter was more substantial overall, yet it does not affect our sectors. The Census Bureau provides industrial crosswalks for the 1970-1980 systems and for the 1990-2000 systems, from which one can gauge how some industries are split or merged into others (Census Bureau (1989), Census Bureau (2003)). These crosswalks are basically a transition matrix for all industries from one classification to the other. A close examination of these transition "probabilities" lead us to conclude that our industries are consistently defined throughout our sample. In the transition from the 1970 system to the 1980 system $99.9 \%$ remain inside each industry; and for the transition from the 1990 system to the 2000 system over $95 \%$ of workers remain inside each industry. This is due to the fact that the functions of our three industries are narrowly and well defined, and due to the fact that they are not too large.

\section{Occupations}

Examining the distribution of occupations within our three industries lead us to choose six occupation groups (henceforth, "occupations"), which describe the major occupational groups in our sample. These are: "Managers and Professionals", "Computer and Mathematics", "Insurance Specialists", "Securities and Financial Asset Sales", "Administration, Including Clerks", and "All the Rest" (janitors, security and miscellaneous). As with industry classifications, major occupational re-classifications occurred in survey year 1983, from the Census 1970 system to the 1980 system, and in survey year 2003, from the Census 1990 system to the 2000 system. Of these two re-classifications, the latter was more substantial. We examined the occupational crosswalks, which are provided by the Census Bureau to make sure that our occupational groups are consistently defined over time (Census Bureau (1989), Census Bureau (2003)). We could not consistently separate "managers" from "professionals" due to re-classifications in survey years 1983 and 2003; some occupations that were defined as "professional" were split and re-classified as "managerial" and vice versa. However, these two groups together are consistently identified, without any "jumps" or "drops" in their employment shares over time. Much effort was devoted to making sure that the other occupation groups are also consistently defined throughout our sample. See the appropriate appendix for a detailed description of occupation groups and how they are constructed. Note that some of these occupations potentially mean different things in different industries. For instance, in Banking the "Managers and Professionals" include "bank officers", but these officers do not exist in the two other industries. Another example from Banking is that bank tellers are a significant part of the "Administration, Including Clerks", but, once again, they do not exist in other industries. However, our more narrowly defined occupations, "Computer and Mathematics", "Insurance Specialists" and "Securities and Financial Asset Sales" are the same in all industries. Table 3 contains the number of observations for each occupation and each year, and the shares of each occupation in the total employment of the finance and Insurance sector, using the Census weights to obtain a representative sample.

\section{Education and experience}

Until survey year 1991 years of education are reported in annual steps, starting with 0 years till 18 years (which also absorbs instances of more than 18 years). Also until survey 
year 1991 we correct years of schooling for individuals who did not complete the last year in school by subtracting one year. This correction is not needed after survey year 1992 . From survey year 1992 and on early school attainment is lumped into groups: 0 years, 1-4 years, 5-6 year and 7-8 years. Also starting in survey year 1992 school attainment starting with high school is marked by degrees, not years, therefore it is not possible to distinguish between, e.g., 13, 14 and 15 years of school. To make our education variable consistent throughout our sample, we adopt the coding that starts in survey year 1992, i.e., we group early school attainment into brackets for all the sample and assign maximal values to each bracket. Also, we group 13, 14 and 15 years of school together and assign 14 years for all individuals within that bracket in all years. In addition, we lump 17 years of schooling together with 16 years, for similar reasons. This makes the education variable categories smooth throughout the sample, and in particular around the 1991-1992 surveys. In our analysis we consider mainly two education categories: less than 4-year college graduates (up to 15 years of school, including 2-year college graduates), and college graduates (16 years of school, including 4-year college graduates, and post-graduates). These groups are sufficient to characterize differences in skill. In some cases where it is not, we separate tertiary education into only college and post-graduate degrees. Experience is potential labor market experience. It is measured as min(age-edu-6;age-18), where 'edu' is years of schooling. The CPS does not contain data on job spells.

\section{Annual hours worked}

In order to compute annual hours worked we multiply the number of weeks worked by average hours worked in a week. Weeks worked are grouped into 7 brackets before survey year 1976. Therefore we impute the average number of weeks worked before survey year 1976 by calculating the average weeks worked within those brackets in later years, by sex (male \female). By this we get a better estimate of typical number of weeks worked for each sex in earlier years. Average hours worked per week are reported from survey year 1976 and on, but not beforehand. Until survey year 1975 only hours last week are reported, so we use those when available. For individuals who worked during the survey but where hours last week are not reported we impute average hours worked by calculating the average hours worked per week in later years by sex and full-time $\backslash$ part-time status (full-time means at least 35 hours a week).

\section{Wages and top-coding}

We deflate all wages reported in the CPS using the deflator for personal consumption expenditures from the Bureau of Economic Analysis. The reference year is 2000. Hourly wages are calculated by dividing annual wage income by number of hours worked. The CPS underestimates the income of individuals who earn very high salaries, due to top-coding of income. Therefore, the wages that we report may not be accurate for certain occupations, Securities and Financial Asset Sales in particular. In our sample, the percent of top-coded observations in the private sector increases from $0.06 \%$ in 1967 to $1.1 \%$ in 1980, after which it fluctuates in the range $0.38 \%-1.6 \%$, due to secular adjustments of the top-coding income limit. However, in the financial sector there are many more incidents of top-coding: in Banking, there are on average twice as many top-coded observations, in Insurance there are on average 2.4 as many top-coded observations, whereas in Other Finance Industries there are on average 13 times as many top-coded observations. This leads to an under-estimation of relative wages in the financial sector. In an attempt to compensate for this, we multiply top-coded incomes in all survey years until 1995 by a factor of 1.75 - which is higher than the traditional factor of 1.4-1.5. From survey years 1996 and on, top-coded incomes are average amounts of actual earnings for 12 socioeconomic cells; therefore we do not adjust them. 


\section{B Construction of occupation cells}

In order to create meaningful, but not-too-small occupation cells, we first tabulated all occupations in each of the three industries, "Banking and Saving", "Other Finance Industries" and "Insurance" separately over time. Merging the industrial classifications for these three industries over time was relatively straightforward, since changes in industrial classifications over the years did not result in any significant re-allocation of workers in these sectors. See description in the text above. The 2-digit occupation classifications did not contain enough information on some occupations of interest, so the tabulation was done at the 3-digit level (the most detailed available). Consistent classifications are available within the following survey year intervals: 1968-71, 1972-82, 1983-2002, 2003-06. For 1968-71, the census 1960 classification was used, for 1972-82 the Census 1970 classification, for 1983-2002 the Census 1980 and 1990 classifications, and for 2003-06 the Census 2000 classification. Census 1980 and 1990 classifications are virtually identical, but there are significant re-allocations of occupations between the 1970 and 1980 systems, and between the 1990 and 2000 systems. Since the classifications change from time to time, much effort went into identifying the relevant classifications across years. This was done by comparing high-frequency occupations from the tabulation with their headings from the CPS documentation. Then, using the apparent occupation groups, time series of occupational shares within each industry were graphed in order to make sure that the groups are consistent across time. Major reclassifications occurred in survey year 1983 and in survey year 2003; in these cases we checked the occupational crosswalks from the Census Bureau to make sure that our occupational groups are consistently identified (Census Bureau (1989), Census Bureau (2003)). Finally, we defined six occupation groups (henceforth, "occupations"), which concisely describe the major occupational groups in our sample in a parsimonious way. These are: "Managers and Professionals", "Computer and Mathematics", "Insurance Specialists", "Securities and Financial Asset Sales", "Administration, Including Clerks", and "All the Rest" (janitors, security and miscellaneous). Some additional adjustments were done by comparing average wages and education levels within 3-digit occupation cells to average wages in our occupational groups. This helped us understand better the nature of some occupational headings and to hint towards where they belong within our occupational groups. In particular, this led us to allocate "supervisor-of..." occupations in survey years 1983-2002 into "Managers and Professionals", since their wages were similar to that group and an order of magnitude higher than closely-labeled occupations. But we did not allocate "first-line supervisors" in CPS 2003-06 into that group, as their wages did not conform to the previous rule.

\section{Managers and Professionals}

Managers are quite heterogeneous. They include chief officers, but also middle management, operation managers, financial managers, human resources managers, etc.'. We found a large range of variation within this group in terms of education. Management-related occupations are part of the managerial occupation classifications in survey years 1983-2002, but are mostly allocated to other occupations in the Census 2000 system and 1970 system. Therefore we allocated managers with professionals in all years. A close examination of the titles and wages of these occupations justifies this allocation. Professionals are also quite heterogeneous in terms of occupation titles, but less so in terms of education levels. The most prevalent occupations in this cell are economists, accountants, analysts and lawyers. Before survey year 1983 bank officers (presumably, branch managers) are allocated to the one classification that is relevant for management in this industry: "Bank officers and financial managers". But from 1983 bank managers are allocated to "professional" classifications. This is evident from the heading of the managerial category that is relevant for Banking from 1983 and from a sharp drop in the share of managers from 1981 to 1982 (data years), which is commensurate with an increase in the share of professionals. Bank 
officers cannot be separately identified before 1983 - so we aggregated "managers" and "professionals" together as one unit throughout the sample in order to keep a consistent group. When keeping these two groups separate, the real wages of each group separately seem to be consistent over time and do not exhibit any jumps due to the change in classification systems aforementioned. In particular, wages of "professionals" do not jump upward after 1983, when bank officers are allocated to that group. Managers' wages are somewhat higher throughout, and start increasing more after 1985. But the wages of Managers and Professionals in Banking commove quite closely; this might reflect the relatively tight hierarchical organizational structure in Banking.

\section{Computer and Mathematics}

This cell is quite homogeneous throughout. Much effort was put into making it consistent through time. Despite significant variance in distribution across education categories, individuals in this cell earn relatively similar wages. This indicates that tasks $\backslash$ productivity in this group do not vary much across education categories. The cell includes computer scientists and systems analysts, computer programmers, software engineers, database administrators, network and computer systems administrators, etc.'. In addition, it also includes mathematicians. The cell does not include actuaries and statisticians for the simple reason that these two occupations appear almost only in Insurance and, therefore, are allocated to the "professionals" cell.

\section{Insurance Specialists}

This cell includes only Insurance agents, adjusters, examiners, investigators and underwriters. Almost all observations in this cell come from the Insurance industry, but there is a significant number of observations in Banking and Saving. "Insurance adjusters, examiners, and investigators" were split from 2003 CPS into two categories ("Claims adjusters, appraisers, examiners, and investigators" and "Insurance claims and policy processing clerks"). We re-allocated them together to get a consistent group.

\section{Securities and Financial Asset Sales}

This cell includes stock, bond, commodity and other asset traders, and personal financial advisors. Almost all observations in this cell come from the Other Finance Industries industry, but there is a significant - and growing - number of observations in the other two industries. Before survey year 1971 (i.e., 1968-70) many individuals that would fit in "Securities and Financial Asset Sales" were actually allocated to broad managerial classifications and cannot be separated.

\section{Administration, Including Clerks}

This cell is probably the most diverse in terms of education levels and wages. It contains a large range of different occupations that operate in offices, like tellers, clerks, secretaries, office assistants - but does not include managers thereof. In the Banking industry this cell includes a large number of bank tellers. In all industries the cell includes a large number of secretaries.

\section{Construction of Matched CPS}

We thank Donghoon Lee for providing us with his methodology. The "Matched CPS" takes advantage of the fact that households in the CPS are sampled for more than a year, in the following pattern. Each household that enters the survey at any given month is sampled for four months, leaves for eight months, and then returns for four more months, after which it exits. Therefore, theoretically, every household that is surveyed in March of any given year must have been surveyed in the previous March, or will be surveyed in the next. Of course, in practice not all individuals get surveyed twice due to survey attrition, non-compliance, etc.'. 
Unfortunately, the CPS does not hold a definitive person ID, by which one could easily match two observations on the same individual from two consecutive surveys. The following methodology is used to match observations on the same individual from two consecutive surveys. We match individual observations from two consecutive surveys by household ID, their "line" within the household (which is an intra-household identifier), state of residence, race, sex and year of birth. These are supplemented with a few more identifiers generated by the CPS (segment number, serial number and a random cluster code). We make sure that there are only two observations within each cell defined by these identifiers and drop all other cells.

Some survey years cannot be matched. Survey year 1968 cannot be matched backwards, because our sample starts with that survey year. Likewise, survey year 2006 cannot be matched backwards, because our sample end with that survey year. Other survey years that cannot be matched for technical reasons are 1971, 1972, 1976, 1985, 1995 and 2001. Approximately $63 \%$ of all observations are actually matched from within survey years that can be matched.

\section{Definition of unemployment}

Here we give the exact definition of our unemployment indicator. A person would get a positive indication of unemployment if:

1. did not work last year and reported: could not find work, looking for work or on layoff.

2. in survey years 1968-1993 major activity in the week before the survey was looking for work.

3. in survey years 1968-1993 did not work last week due to being laid-off.

4. in survey years 1994-2006 reported being on layoff or looking for work.

5. in survey years 1968-1988 reported reason for working part year was looking for work or being unemployed.

6. reported positive number of weeks looking for work last year.

7. reported positive number of weeks being unemployed last year.

Since the sample for our transition regressions includes only people that were not unemployed in the first year they were surveyed, this eventually reduces our sample. Table A contains the number of observations in the transition regressions for every year that could be matched. 


\section{References}

Acemoglu, D. (1998): "Why Do New Technologies Complement Skills? Directed Technical Change and Wage Inequality," The Quarterly Journal of Economics, 113(4), 10551089 .

Autor, D., L. Katz, And A. Krueger (1998): "Computing Inequality: Have Computers Changed the Labor Market?," Quarterly Journal of Economics, 113(4), 1169-1214.

Autor, D. H., L. F. Katz, and M. S. Kearney (2006): "The Polarization of the U.S. Labor Market," American Economic Review, 96(2), 189-194.

Autor, D. H., F. Levy, and R. J. Murnane (2002): "Upstairs, Downstairs: Computers and Skills on Two Floors of a Large Bank," Industrial and Labor Relations Review, 55, 432-447.

Baumol, W. J. (1967): "Macroeconomics of Unbalanced Growth: The Anatomy of the Urban Crisis," American Economic Review, 57, 415-426.

Baumol, W. J. (1990): "Entrepreneurship: Productive, Unproductive, and Destructive," Journal of Political Economy, 98, 893-921.

Buera, F. J., And J. P. Kaboski (2006): "The Rise of the Service Economy," Working Paper, Northwestern University.

Card, D., and T. Lemieux (2001): "Can Falling Supply Explain the Rising Return to College for Younger Men? A Cohort-Based Analysis.," Quarterly Journal of Economics, 116(2), 705-746.

Census Bureau (1989): "The Relationship Between The 1970 and 1980 Industry and Occupation Classification Systems," Discussion Paper Technical Paper 59.

_ (2003): "The Relationship Between the 1990 Census and Census 2000 Industry and Occupation Classification Systems," Discussion Paper Technical Paper 65.

Deschênes, O. (2006): "Unobserved Ability, Comparative Advantage and the Rising Return to Education in the United States 1979-2002," Working Paper, University of California, Santa Barbara.

Kaplan, S. N., and J. Rauh (2007): "Wall Street and Main Street: What Contributes to the Rise in the Highest Incomes?," NBER Working Paper 13270.

Katz, L. F., And K. M. Murphy (1992): "Changes in Relative Wages, 1963-1987: Supply and Demand Factors," Quarterly Journal of Economics, 107(1), 35-78.

Kuznets, S. (1957): "Quantitative Aspects of the Economic Growth of Nations: Industrial Distribution of National Product and Labor Force," Economic Development and Cultural Change, 5, 1-111.

Lemieux, T. (2006): "Increasing Residual Wage Inequality: Composition Effects, Noisy Data, or Rising Demand for Skill?," American Economic Review, 96(3), 461-498.

Miller, M. H. (1986): "Financial Innovation: The Last Twenty Years and the Next," Journal of Financial and Quantitative Analysis, 21(4), 459-471. 
MinceR, J. (1997): "Changes in Wage Inequality, 1970-1990," in Research in Labor Economics, ed. by S. W. Polachek, pp. 1-18, London. JAI Press.

Murphy, K. M., A. Shleifer, and R. W. Vishny (1991): "The Allocation of Talent: Implications for Growth," The Quarterly Journal of Economics, 106, 503-530.

Philippon, T. (2007): "Financiers versus Engineers: Should the Financial Sector Be Taxed or Subsidized?," Working Paper, NYU.

Ruhm, C. J. (1991): "Are Workers Permanently Scarred by Job Displacements?," The American Economic Review, 81(1), 319-324.

Silber, W. L. (1983): "The Process of Financial Innovation," The American Economic Review, 73(2), 89-95.

Stigler, G. J. (1956): "Trends in Employment in the Service Industries," General Series. NBER.

Tufano, P. (2004): "Financial Innovation," in The Handbook of the Economics of Finance, ed. by M. H. George Constantinides, and R. Stulz. North Holland. 
Appendix Table A: Matched CPS Sample

\begin{tabular}{|c|c|c|c|}
\hline Year & Matched observations & Year & Matched observations \\
\hline 1967 & 14,318 & 1986 & 17,441 \\
\hline 1968 & 13,683 & 1987 & 16,568 \\
\hline 1969 & 15,004 & 1988 & 17,555 \\
\hline 1970 & . & 1989 & 19,146 \\
\hline 1971 & . & 1990 & 18,393 \\
\hline 1972 & 9,299 & 1991 & 17,634 \\
\hline 1973 & 13,882 & 1992 & 13,497 \\
\hline 1974 & 8,857 & 1993 & 12,704 \\
\hline 1975 & . & 1994 & . \\
\hline 1976 & 15,761 & 1995 & 17,461 \\
\hline 1977 & 15,984 & 1996 & 17,794 \\
\hline 1978 & 16,516 & 1997 & 17,639 \\
\hline 1979 & 20,268 & 1998 & 17,979 \\
\hline 1980 & 18,014 & 1999 & 18,406 \\
\hline 1981 & 17,519 & 2000 & \\
\hline 1982 & 16,525 & 2001 & 25,253 \\
\hline 1983 & 16,256 & 2002 & 25,390 \\
\hline 1984 & . & 2003 & 22,162 \\
\hline \multirow[t]{2}{*}{1985} & 16,899 & 2004 & 23,498 \\
\hline & & TOTAL & 547,305 \\
\hline
\end{tabular}

Notes: This sample takes into account the number of successful matches in the CPS and the following restrictions. Individuals in the first matched year must be in the labor force, employed in the private sector; in the second matched year individuals just need to be in the labor force (not retired, in school full time, etc'). 
Table 1: Classification of Tasks and Industries

Industries in Financial Sector

Banking

Insurance

Rest of Finance
Banks, thrifts and saving institutions

Insurance companies

Investment banks, mutual and pension funds, private equity funds, brokers and dealers

Occupations in Financial Sector

Managers and professionals

Computer and matchematics

Insurance specialists

Securities and financial asset sales

Administration

Other
Bank officers, financial managers, economists, financial analysts, etc.

Computer scientists and engineers, systems analysts, programmers, database administrators and mathematicians

Insurance sales agents, actuaries and statisticians

Securities, commodities, and financial services sales agents, and personal financial advisors

Clerical jobs and bank tellers

Janitors, private security and miscelanous 
Table 2: Number of Observations and Employment Shares, by Industry

\begin{tabular}{|c|c|c|c|c|c|c|c|}
\hline \multirow[b]{2}{*}{ Year } & \multirow{2}{*}{$\begin{array}{c}\text { Non Financial } \\
\text { Private Sector } \\
\text { Obs. }\end{array}$} & \multicolumn{2}{|c|}{ Banking } & \multicolumn{2}{|c|}{ Other Finance Industries } & \multicolumn{2}{|c|}{ Insurance } \\
\hline & & Obs. & Empl. Share & Obs. & Empl. Share & Obs. & Empl. Share \\
\hline 1967 & 56002 & 1046 & 0.0181 & 149 & 0.0026 & 1008 & 0.0173 \\
\hline 1968 & 57229 & 1039 & 0.0176 & 197 & 0.0033 & 1001 & 0.0168 \\
\hline 1969 & 55806 & 1118 & 0.0193 & 227 & 0.0040 & 1030 & 0.0179 \\
\hline 1970 & 56644 & 1098 & 0.0188 & 196 & 0.0033 & 1140 & 0.0195 \\
\hline 1971 & 54208 & 1049 & 0.0186 & 167 & 0.0030 & 1121 & 0.0198 \\
\hline 1972 & 53218 & 1112 & 0.0201 & 190 & 0.0034 & 1048 & 0.0189 \\
\hline 1973 & 53695 & 1105 & 0.0198 & 183 & 0.0033 & 1045 & 0.0187 \\
\hline 1974 & 52654 & 1217 & 0.0220 & 142 & 0.0026 & 1056 & 0.0191 \\
\hline 1975 & 53979 & 1154 & 0.0205 & 154 & 0.0028 & 1009 & 0.0181 \\
\hline 1976 & 65773 & 1382 & 0.0203 & 179 & 0.0029 & 1124 & 0.0171 \\
\hline 1977 & 64855 & 1394 & 0.0211 & 171 & 0.0028 & 1128 & 0.0178 \\
\hline 1978 & 65574 & 1514 & 0.0221 & 185 & 0.0030 & 1216 & 0.0190 \\
\hline 1979 & 77736 & 1812 & 0.0228 & 207 & 0.0030 & 1408 & 0.0185 \\
\hline 1980 & 77096 & 1919 & 0.0249 & 237 & 0.0035 & 1452 & 0.0195 \\
\hline 1981 & 68789 & 1749 & 0.0245 & 267 & 0.0041 & 1294 & 0.0189 \\
\hline 1982 & 67709 & 1708 & 0.0244 & 276 & 0.0045 & 1250 & 0.0186 \\
\hline 1983 & 67173 & 1732 & 0.0250 & 290 & 0.0045 & 1293 & 0.0196 \\
\hline 1984 & 68834 & 1840 & 0.0256 & 361 & 0.0055 & 1253 & 0.0180 \\
\hline 1985 & 67826 & 1780 & 0.0254 & 318 & 0.0047 & 1343 & 0.0193 \\
\hline 1986 & 67575 & 1798 & 0.0254 & 357 & 0.0054 & 1275 & 0.0183 \\
\hline 1987 & 67589 & 1955 & 0.0275 & 408 & 0.0057 & 1400 & 0.0201 \\
\hline 1988 & 63617 & 1752 & 0.0266 & 350 & 0.0057 & 1314 & 0.0201 \\
\hline 1989 & 69460 & 1923 & 0.0260 & 434 & 0.0062 & 1474 & 0.0205 \\
\hline 1990 & 68970 & 1842 & 0.0249 & 344 & 0.0049 & 1491 & 0.0208 \\
\hline 1991 & 68015 & 1820 & 0.0246 & 331 & 0.0050 & 1400 & 0.0204 \\
\hline 1992 & 67035 & 1746 & 0.0247 & 377 & 0.0059 & 1286 & 0.0187 \\
\hline 1993 & 64307 & 1714 & 0.0257 & 363 & 0.0059 & 1313 & 0.0201 \\
\hline 1994 & 64488 & 1636 & 0.0239 & 444 & 0.0065 & 1272 & 0.0190 \\
\hline 1995 & 57499 & 1357 & 0.0223 & 356 & 0.0062 & 1164 & 0.0200 \\
\hline 1996 & 58939 & 1431 & 0.0226 & 369 & 0.0064 & 1099 & 0.0185 \\
\hline 1997 & 58096 & 1466 & 0.0237 & 391 & 0.0066 & 1212 & 0.0204 \\
\hline 1998 & 58670 & 1490 & 0.0238 & 426 & 0.0076 & 1178 & 0.0197 \\
\hline 1999 & 60287 & 1523 & 0.0241 & 487 & 0.0083 & 1096 & 0.0176 \\
\hline 2000 & 57956 & 1452 & 0.0235 & 468 & 0.0086 & 1087 & 0.0190 \\
\hline 2001 & 95774 & 2436 & 0.0234 & 703 & 0.0078 & 1806 & 0.0184 \\
\hline 2002 & 94455 & 2532 & 0.0249 & 812 & 0.0079 & 1803 & 0.0190 \\
\hline 2003 & 92403 & 2490 & 0.0255 & 700 & 0.0077 & 1853 & 0.0198 \\
\hline 2004 & 90753 & 2435 & 0.0254 & 706 & 0.0081 & 1816 & 0.0196 \\
\hline 2005 & 90427 & 2396 & 0.0249 & 745 & 0.0087 & 1659 & 0.0173 \\
\hline
\end{tabular}

Notes: Obs. is the number of observations in the March CPS of the following year (data for 2005 is collected in the CPS of March 2006).

Employment share is the share in total private sector employment, in terms of full-time equivalents, computed using the CPS weight to obtain a representative sample. 
Table 3: Number of Observations and Employment Shares, by Occupation

\begin{tabular}{|c|c|c|c|c|c|c|c|c|c|c|c|c|}
\hline \multirow{2}{*}{$\begin{array}{l}\text { Occupation } \\
\text { year }\end{array}$} & \multicolumn{2}{|c|}{ Managers \& Professionals } & \multicolumn{2}{|c|}{ Computer \& Mathematics } & \multicolumn{2}{|c|}{ Insurance Specialists } & \multicolumn{2}{|c|}{ Securities and Asset Sales } & \multicolumn{2}{|c|}{ Administration and Clerks } & \multicolumn{2}{|c|}{ Others } \\
\hline & Obs. & Empl. Share & Obs. & Empl. Share & Obs. & Empl. Share & Obs. & Empl. Share & Obs. & Empl. Share & Obs. & Empl. Share \\
\hline 1967 & 554 & 0.252 & o & & 278 & 0.127 & 12 & 0.006 & 1272 & 0.576 & 87 & 0.039 \\
\hline 1968 & 534 & 0.238 & & & 274 & 0.122 & 5 & 0.002 & 1363 & 0.609 & 61 & 0.028 \\
\hline 1969 & 561 & 0.232 & . & . & 230 & 0.095 & 15 & 0.006 & 1486 & 0.630 & 83 & 0.036 \\
\hline 1970 & 527 & 0.217 & 27 & 0.011 & 362 & 0.147 & 66 & 0.026 & 1382 & 0.571 & 70 & 0.027 \\
\hline 1971 & 483 & 0.206 & 25 & 0.011 & 334 & 0.141 & 59 & 0.025 & 1361 & 0.585 & 75 & 0.032 \\
\hline 1972 & 513 & 0.217 & 18 & 0.008 & 335 & 0.142 & 65 & 0.027 & 1349 & 0.576 & 70 & 0.030 \\
\hline 1973 & 544 & 0.232 & 30 & 0.013 & 318 & 0.136 & 74 & 0.032 & 1293 & 0.556 & 74 & 0.032 \\
\hline 1974 & 540 & 0.224 & 29 & 0.012 & 331 & 0.138 & 50 & 0.020 & 1390 & 0.575 & 75 & 0.031 \\
\hline 1975 & 539 & 0.235 & 29 & 0.012 & 288 & 0.126 & 48 & 0.020 & 1335 & 0.574 & 78 & 0.033 \\
\hline 1976 & 662 & 0.242 & 20 & 0.009 & 316 & 0.117 & 52 & 0.021 & 1554 & 0.577 & 81 & 0.034 \\
\hline 1977 & 680 & 0.253 & 32 & 0.012 & 324 & 0.119 & 63 & 0.026 & 1526 & 0.565 & 68 & 0.025 \\
\hline 1978 & 722 & 0.242 & 35 & 0.013 & 316 & 0.109 & 64 & 0.024 & 1698 & 0.582 & 80 & 0.029 \\
\hline 1979 & 800 & 0.235 & 48 & 0.015 & 349 & 0.101 & 67 & 0.023 & 2068 & 0.597 & 95 & 0.028 \\
\hline 1980 & 919 & 0.248 & 38 & 0.012 & 388 & 0.106 & 90 & 0.028 & 2066 & 0.577 & 107 & 0.030 \\
\hline 1981 & 794 & 0.243 & 54 & 0.017 & 346 & 0.104 & 123 & 0.041 & 1898 & 0.564 & 95 & 0.032 \\
\hline 1982 & 860 & 0.271 & 51 & 0.017 & 306 & 0.090 & 116 & 0.040 & 1765 & 0.541 & 136 & 0.041 \\
\hline 1983 & 971 & 0.297 & 65 & 0.021 & 289 & 0.086 & 117 & 0.034 & 1747 & 0.520 & 126 & 0.043 \\
\hline 1984 & 976 & 0.287 & 60 & 0.017 & 273 & 0.078 & 161 & 0.050 & 1866 & 0.537 & 118 & 0.032 \\
\hline 1985 & 986 & 0.283 & 60 & 0.016 & 310 & 0.090 & 141 & 0.042 & 1830 & 0.535 & 114 & 0.033 \\
\hline 1986 & 998 & 0.296 & 65 & 0.020 & 286 & 0.080 & 160 & 0.048 & 1814 & 0.523 & 107 & 0.034 \\
\hline 1987 & 1110 & 0.294 & 81 & 0.023 & 295 & 0.075 & 198 & 0.054 & 1950 & 0.519 & 129 & 0.035 \\
\hline 1988 & 1126 & 0.328 & 76 & 0.024 & 281 & 0.082 & 167 & 0.051 & 1666 & 0.485 & 100 & 0.030 \\
\hline 1989 & 1222 & 0.320 & 94 & 0.026 & 337 & 0.092 & 158 & 0.042 & 1897 & 0.487 & 123 & 0.033 \\
\hline 1990 & 1157 & 0.309 & 90 & 0.026 & 304 & 0.085 & 157 & 0.045 & 1868 & 0.510 & 101 & 0.026 \\
\hline 1991 & 1130 & 0.313 & 71 & 0.022 & 291 & 0.082 & 155 & 0.047 & 1778 & 0.501 & 126 & 0.035 \\
\hline 1992 & 1147 & 0.339 & 84 & 0.026 & 287 & 0.087 & 150 & 0.049 & 1645 & 0.471 & 96 & 0.028 \\
\hline 1993 & 1171 & 0.346 & 97 & 0.027 & 279 & 0.081 & 166 & 0.054 & 1578 & 0.460 & 99 & 0.032 \\
\hline 1994 & 1170 & 0.342 & 107 & 0.031 & 261 & 0.080 & 192 & 0.059 & 1520 & 0.457 & 102 & 0.031 \\
\hline 1995 & 995 & 0.344 & 81 & 0.029 & 264 & 0.094 & 171 & 0.061 & 1272 & 0.437 & 94 & 0.034 \\
\hline 1996 & 1034 & 0.358 & 87 & 0.032 & 240 & 0.087 & 188 & 0.068 & 1273 & 0.431 & 77 & 0.025 \\
\hline 1997 & 1105 & 0.363 & 83 & 0.027 & 261 & 0.083 & 188 & 0.064 & 1339 & 0.435 & 93 & 0.028 \\
\hline 1998 & 1200 & 0.398 & 95 & 0.032 & 243 & 0.076 & 198 & 0.068 & 1263 & 0.398 & 95 & 0.028 \\
\hline 1999 & 1166 & 0.377 & 103 & 0.035 & 218 & 0.067 & 229 & 0.075 & 1289 & 0.413 & 101 & 0.033 \\
\hline 2000 & 1100 & 0.368 & 106 & 0.040 & 252 & 0.087 & 210 & 0.076 & 1237 & 0.396 & 102 & 0.033 \\
\hline 2001 & 1885 & 0.388 & 157 & 0.030 & 347 & 0.076 & 358 & 0.078 & 2036 & 0.396 & 162 & 0.032 \\
\hline 2002 & 2162 & 0.417 & 227 & 0.045 & 341 & 0.079 & 400 & 0.077 & 1830 & 0.347 & 187 & 0.035 \\
\hline 2003 & 2098 & 0.410 & 270 & 0.055 & 363 & 0.072 & 393 & 0.084 & 1790 & 0.353 & 129 & 0.027 \\
\hline 2004 & 2065 & 0.408 & 297 & 0.058 & 322 & 0.069 & 401 & 0.088 & 1729 & 0.350 & 143 & 0.027 \\
\hline 2005 & 2081 & 0.431 & 247 & 0.049 & 282 & 0.057 & 394 & 0.090 & 1660 & 0.343 & 136 & 0.030 \\
\hline
\end{tabular}

Notes: Obs. is the number of observations in the March CPS of the following year (data for 2005 is collected in the CPS of March 2006). Employment share is the share of employment in Finance and Insurance, in terms of full-time equivalents, computed using the CPS weight to obtain representative sample. 
Table 4: Relative Wages in the Financial Sector, Controlling for Education

\begin{tabular}{|c|c|c|c|c|c|c|c|c|}
\hline Sample & $1967-1970$ & $71-75$ & $76-80$ & $81-85$ & $86-90$ & $91-95$ & $96-00$ & 2001-2005 \\
\hline \multirow[t]{2}{*}{ Finance } & 0.03488 & 0.0331 & 0.04335 & 0.0664 & 0.12681 & 0.14797 & 0.17433 & 0.19897 \\
\hline & [0.00489] & {$[0.00468]$} & {$[0.00404]$} & {$[0.00406]$} & {$[0.00416]$} & {$[0.00442]$} & [0.00472] & {$[0.00378]$} \\
\hline \multirow[t]{2}{*}{ White } & 0.2011 & 0.15176 & 0.10651 & 0.11517 & 0.10216 & 0.08509 & 0.06909 & 0.07165 \\
\hline & {$[0.00371]$} & [0.00354] & {$[0.00295]$} & {$[0.00300]$} & {$[0.00304]$} & [0.00305] & {$[0.00316]$} & [0.00232] \\
\hline \multirow[t]{2}{*}{ Male } & 0.45759 & 0.4609 & 0.45297 & 0.40061 & 0.36272 & 0.31803 & 0.31979 & 0.31526 \\
\hline & {$[0.00245]$} & {$[0.00231]$} & [0.00191] & {$[0.00197]$} & {$[0.00203]$} & {$[0.00210]$} & {$[0.00220]$} & [0.00180] \\
\hline \multirow[t]{2}{*}{ Married } & 0.08004 & 0.08278 & 0.07528 & 0.06951 & 0.0844 & 0.09803 & 0.10024 & 0.11465 \\
\hline & {$[0.00275]$} & {$[0.00257]$} & {$[0.00209]$} & {$[0.00214]$} & {$[0.00218]$} & {$[0.00226]$} & {$[0.00236]$} & [0.00196] \\
\hline \multirow[t]{2}{*}{ Urban } & 0.02579 & 0.01872 & 0.01531 & 0.01601 & 0.02032 & 0.01204 & 0.00482 & 0.00167 \\
\hline & {$[0.00227]$} & {$[0.00225]$} & {$[0.00210]$} & {$[0.00222]$} & {$[0.00235]$} & {$[0.00248]$} & {$[0.00256]$} & [0.00214] \\
\hline \multirow[t]{2}{*}{ Potential Experience } & 0.02751 & 0.03475 & 0.03525 & 0.03612 & 0.03674 & 0.03551 & 0.03148 & 0.03207 \\
\hline & {$[0.00030]$} & {$[0.00029]$} & {$[0.00026]$} & [0.00029] & {$[0.00030]$} & {$[0.00031]$} & {$[0.00032]$} & {$[0.00027]$} \\
\hline \multirow[t]{2}{*}{$(\text { Potential Experience })^{2}$} & -0.00047 & -0.0006 & -0.00058 & -0.00058 & -0.00058 & -0.00054 & -0.00048 & -0.00051 \\
\hline & {$[0.00001]$} & {$[0.00001]$} & {$[0.00001]$} & {$[0.00001]$} & {$[0.00001]$} & {$[0.00001]$} & {$[0.00001]$} & [0.00001] \\
\hline \multirow[t]{2}{*}{ Edu $=12$ Years } & 0.1879 & 0.19456 & 0.22173 & 0.24228 & 0.24929 & 0.27398 & 0.29507 & 0.28956 \\
\hline & [0.00252] & [0.00263] & [0.00248] & {$[0.00287]$} & {$[0.00318]$} & {$[0.00378]$} & [0.00399] & [0.00343] \\
\hline \multirow[t]{2}{*}{$13 \leq \mathrm{Edu} \leq 15$ Years } & 0.32265 & 0.33139 & 0.35047 & 0.39876 & 0.43382 & 0.46178 & 0.48386 & 0.48714 \\
\hline & {$[0.00349]$} & {$[0.00340]$} & {$[0.00297]$} & {$[0.00330]$} & {$[0.00355]$} & [0.00392] & [0.00409] & [0.00348] \\
\hline \multirow[t]{2}{*}{$16 \leq \mathrm{Edu} \leq 17$ Years } & 0.54919 & 0.55736 & 0.5582 & 0.62896 & 0.70424 & 0.77204 & 0.80378 & 0.81657 \\
\hline & {$[0.00367]$} & {$[0.00355]$} & {$[0.00313]$} & {$[0.00340]$} & {$[0.00366]$} & {$[0.00417]$} & [0.00432] & [0.00364] \\
\hline \multirow[t]{2}{*}{ Edu $\geq 18$ Years } & 0.66503 & 0.69095 & 0.73268 & 0.81891 & 0.90028 & 1.02087 & 1.07548 & 1.10141 \\
\hline & {$[0.00554]$} & [0.00502] & {$[0.00414]$} & {$[0.00422]$} & {$[0.00442]$} & {$[0.00474]$} & [0.00495] & [0.00408] \\
\hline Obs & 130608 & 157919 & 226316 & 227449 & 242399 & 233500 & 223906 & 358991 \\
\hline $\mathrm{R}^{2}$ & 0.41 & 0.41 & 0.4 & 0.38 & 0.36 & 0.36 & 0.35 & 0.35 \\
\hline
\end{tabular}

Notes: Dependent variable is log of annual wage earnings. The sample includes only full-time-full-year workers (at least 40 week per year, at least 35 hours per week on average). Finance is a dummy for the financial sector. Married is a dummy variable for individuals who are married and not separated. Urban is a dummy variable for individuals who live in an MSA (Census metropolitan statistical area) in a central city (until 2003) or in a principal city (after 2004). Potential Experience is calculated as min \{age-years of school-6, age-18\}. The control group for education consists of individuals with 11 years of schooling or less. Edu $=12$ Years is a dummy variable for individuals who have exactly 12 years of education. $13 \leq$ Edu $\leq 15$ Years is a dummy variable for individuals who have between 13 and 15 years of education, and so on. Each column reports the estimates over a 5-year period (the first column has only 4 years). All regressions include intra-period year dummies, which are not reported. Standard errors in brackets. Data: March CPS. 
Table 5: Relative Wages in the Financial Sector, within Education Groups.

\begin{tabular}{|c|c|c|c|c|c|c|c|c|}
\hline Sample & $1967-1970$ & 71-75 & $76-80$ & $81-85$ & $86-90$ & 91-95 & $96-00$ & 2001-2005 \\
\hline \multirow[t]{2}{*}{ Edu $=12$ Years } & 0.18853 & 0.1955 & 0.22368 & 0.24424 & 0.25149 & 0.27573 & 0.29691 & 0.2906 \\
\hline & {$[0.00256]$} & {$[0.00266]$} & {$[0.00251]$} & [0.00290] & {$[0.00322]$} & [0.00384] & {$[0.00405]$} & [0.00349] \\
\hline \multirow[t]{2}{*}{$13 \leq \mathrm{Edu} \leq 15$ Years } & 0.32546 & 0.33374 & 0.35388 & 0.40447 & 0.43916 & 0.46631 & 0.48917 & 0.49213 \\
\hline & [0.00358] & {$[0.00348]$} & {$[0.00303]$} & {$[0.00337]$} & [0.00361] & {$[0.00398]$} & {$[0.00416]$} & {$[0.00355]$} \\
\hline \multirow[t]{2}{*}{ Edu $\geq 16$ Years } & 0.58276 & 0.59595 & 0.60807 & 0.68784 & 0.76601 & 0.85787 & 0.8948 & 0.91506 \\
\hline & {$[0.00338]$} & {$[0.00330]$} & {$[0.00292]$} & [0.00321] & {$[0.00348]$} & [0.00399] & {$[0.00415]$} & [0.00353] \\
\hline \multirow[t]{2}{*}{ Edu $=12$ in Finance } & -0.04836 & -0.0547 & -0.0801 & -0.1155 & -0.12357 & -0.13635 & -0.18547 & -0.16013 \\
\hline & {$[0.01688]$} & {$[0.01985]$} & {$[0.02145]$} & {$[0.02489]$} & {$[0.02927]$} & [0.04261] & {$[0.04400]$} & {$[0.03634]$} \\
\hline \multirow[t]{2}{*}{ Edu 13 to 15 in Finance } & -0.07921 & -0.07406 & -0.09739 & -0.16074 & -0.15938 & -0.16379 & -0.225 & -0.21525 \\
\hline & {$[0.01883]$} & {$[0.02113]$} & {$[0.02222]$} & {$[0.02543]$} & [0.02968] & [0.04262] & [0.04386] & {$[0.03615]$} \\
\hline \multirow[t]{2}{*}{ Edu $\geq 16$ in Finance } & -0.10067 & -0.07981 & -0.0334 & -0.0934 & -0.09439 & -0.11884 & -0.1677 & -0.15747 \\
\hline & {$[0.01910]$} & {$[0.02103]$} & {$[0.02215]$} & [0.02523] & [0.02943] & [0.04252] & [0.04373] & {$[0.03600]$} \\
\hline \multirow[t]{2}{*}{ Finance } & 0.09271 & 0.09114 & 0.10731 & 0.17751 & 0.24032 & 0.27375 & 0.34998 & 0.35888 \\
\hline & {$[0.01546]$} & {$[0.01869]$} & {$[0.02064]$} & {$[0.02411]$} & [0.02853] & [0.04188] & {$[0.04307]$} & {$[0.03552]$} \\
\hline \multirow[t]{2}{*}{ White } & 0.20103 & 0.15202 & 0.10718 & 0.11644 & 0.10307 & 0.08652 & 0.06985 & 0.07189 \\
\hline & {$[0.00371]$} & {$[0.00355]$} & {$[0.00296]$} & {$[0.00302]$} & {$[0.00305]$} & {$[0.00307]$} & [0.00319] & [0.00234] \\
\hline \multirow[t]{2}{*}{ Male } & 0.45996 & 0.46358 & 0.45488 & 0.40291 & 0.36464 & 0.31975 & 0.32069 & 0.31596 \\
\hline & {$[0.00246]$} & {$[0.00232]$} & {$[0.00192]$} & {$[0.00198]$} & {$[0.00204]$} & {$[0.00213]$} & {$[0.00223]$} & {$[0.00183]$} \\
\hline \multirow[t]{2}{*}{ Married } & 0.07973 & 0.0826 & 0.07515 & 0.07027 & 0.08514 & 0.10018 & 0.10339 & 0.1186 \\
\hline & {$[0.00276]$} & {$[0.00257]$} & {$[0.00210]$} & {$[0.00214]$} & [0.00219] & [0.00228] & {$[0.00238]$} & [0.00198] \\
\hline \multirow[t]{2}{*}{ Urban } & 0.02597 & 0.01932 & 0.0162 & 0.01708 & 0.02207 & 0.01459 & 0.00838 & 0.0052 \\
\hline & {$[0.00228]$} & {$[0.00225]$} & {$[0.00211]$} & {$[0.00223]$} & {$[0.00236]$} & {$[0.00250]$} & {$[0.00258]$} & {$[0.00216]$} \\
\hline \multirow[t]{2}{*}{ Potential Experience } & 0.0277 & 0.035 & 0.03568 & 0.03683 & 0.03759 & 0.0368 & 0.03252 & 0.03288 \\
\hline & {$[0.00030]$} & {$[0.00029]$} & {$[0.00026]$} & {$[0.00029]$} & {$[0.00030]$} & [0.00031] & {$[0.00033]$} & {$[0.00027]$} \\
\hline \multirow[t]{2}{*}{$(\text { Potential Experience })^{2}$} & -0.00048 & -0.0006 & -0.00059 & -0.00059 & -0.00059 & -0.00057 & -0.0005 & -0.00052 \\
\hline & {$[0.00001]$} & {$[0.00001]$} & {$[0.00001]$} & {$[0.00001]$} & {$[0.00001]$} & [0.00001] & {$[0.00001]$} & {$[0.00001]$} \\
\hline Obs & 130608 & 157919 & 226316 & 227449 & 242399 & 233500 & 223906 & 358991 \\
\hline $\mathrm{R}^{2}$ & 0.41 & 0.4 & 0.39 & 0.37 & 0.35 & 0.34 & 0.34 & 0.34 \\
\hline
\end{tabular}


Table 6: Unemployment Risk

\begin{tabular}{|c|c|c|c|c|c|c|c|c|}
\hline Sample & $1967-1970$ & $71-75$ & $76-80$ & 81-85 & $86-90$ & 91-95 & $96-00$ & 2001-2005 \\
\hline \multirow[t]{2}{*}{ Finance } & -0.55163 & -0.48595 & -0.51157 & -0.39715 & -0.22957 & -0.09342 & -0.19605 & -0.13666 \\
\hline & [0.12997] & [0.12223] & [0.07282] & [0.07669] & {$[0.06556]$} & [0.08058] & [0.08940] & [0.07263] \\
\hline \multirow[t]{2}{*}{ Full Time } & -0.6888 & -0.64956 & -0.6678 & -0.6518 & -0.71851 & -0.72143 & -0.73918 & -0.75474 \\
\hline & [0.04573] & [0.04682] & [0.02845] & [0.03383] & {$[0.03106]$} & [0.04054] & [0.04194] & {$[0.03700]$} \\
\hline \multirow[t]{2}{*}{ White } & -0.24414 & -0.26895 & -0.27827 & -0.25777 & -0.24927 & -0.11512 & -0.23705 & -0.22088 \\
\hline & [0.06493] & {$[0.06572]$} & [0.03952] & [0.04450] & [0.04011] & [0.05084] & {$[0.05044]$} & [0.04001] \\
\hline \multirow[t]{2}{*}{ Male } & 0.13284 & 0.09335 & 0.12484 & 0.26709 & 0.17983 & 0.20923 & 0.18362 & 0.25813 \\
\hline & [0.04322] & {$[0.04265]$} & [0.02592] & [0.02935] & [0.02695] & [0.03431] & [0.03553] & [0.02994] \\
\hline \multirow[t]{2}{*}{ Married } & -0.28398 & -0.15524 & -0.26885 & -0.20554 & -0.22744 & -0.30026 & -0.41706 & -0.41784 \\
\hline & [0.04705] & [0.04754] & [0.02832] & [0.03198] & [0.02939] & [0.03695] & {$[0.03797]$} & [0.03198] \\
\hline \multirow[t]{2}{*}{ Urban } & 0.05337 & 0.03043 & 0.02159 & 0.06543 & 0.0692 & 0.10191 & 0.0425 & 0.0438 \\
\hline & {$[0.04457]$} & [0.04612] & [0.03039] & [0.03445] & [0.03282] & [0.04120] & [0.04222] & [0.03635] \\
\hline \multirow[t]{2}{*}{ Potential Experience } & -0.01853 & -0.02353 & -0.02637 & -0.02288 & -0.01941 & -0.0192 & -0.01406 & -0.01132 \\
\hline & {$[0.00157]$} & [0.00161] & [0.00103] & [0.00118] & [0.00112] & {$[0.00144]$} & {$[0.00147]$} & [0.00125] \\
\hline \multirow[t]{2}{*}{ Edu $=12$ Years } & -0.3306 & -0.32743 & -0.28063 & -0.2161 & -0.23232 & -0.21526 & -0.19161 & -0.13053 \\
\hline & {$[0.04565]$} & {$[0.04790]$} & {$[0.03064]$} & {$[0.03648]$} & {$[0.03552]$} & {$[0.05014]$} & [0.05219] & [0.04630] \\
\hline \multirow[t]{2}{*}{$13 \leq$ Edu $\leq 15$ Years } & -0.51242 & -0.45212 & -0.48243 & -0.53541 & -0.49445 & -0.44932 & -0.35927 & -0.28709 \\
\hline & [0.06535] & [0.06228] & [0.03793] & [0.04415] & {$[0.04126]$} & [0.05229] & {$[0.05351]$} & [0.04684] \\
\hline \multirow[t]{2}{*}{$16 \leq$ Edu $\leq 17$ Years } & -1.39368 & -1.07073 & -0.93185 & -1.02105 & -0.85484 & -0.8367 & -0.72462 & -0.63434 \\
\hline & {$[0.10816]$} & {$[0.08563]$} & {$[0.04866]$} & [0.05451] & [0.04919] & {$[0.06437]$} & [0.06470] & [0.05513] \\
\hline \multirow[t]{2}{*}{ Edu $\geq 18$ Years } & -1.28817 & -1.61834 & -1.56246 & -1.57639 & -1.14617 & -1.12689 & -1.1033 & -0.98919 \\
\hline & {$[0.17475]$} & {$[0.17126]$} & [0.09090] & [0.09203] & {$[0.07164]$} & {$[0.08757]$} & [0.09209] & [0.07332] \\
\hline Obs & 43005 & 32038 & 86543 & 67199 & 89103 & 61296 & 71818 & 96303 \\
\hline
\end{tabular}

Notes: Logit regressions for individuals employed in the private sector at time t. Dependent variable is 1 if individual is unemployed at time $t+1$ (see appendix for exact definition of unemployed) and zero otherwise. Finance is a dummy variable for the financial sector. Married is a dummy variable for individuals who are married and not separated. Urban is a dummy variable for individuals who live in an MSA (Census metropolitan statistical area) in a central city (unti 2003) or in a principal city (after 2004). Potential Experience is calculated as min \{age-years of school-6, age-18\}. The control group for education consists of individuals with 11 years of schooling or less. Edu = 12 Years is a dummy variable for individuals who have exactly 12 years of education. 13 Edu $\leq 15$ Years is a dummy variable for individuals who have between 13 and 15 years of education, and so on. Each column reports the estimates over a 5 -year perio (the first column has only 4 years). All regressions include intra-period year dummies, which are not reported. Standard errors in brackets. Data: March CPS. 
Table 7: Unemployment Risk, Controlling for Current Wage

\begin{tabular}{|c|c|c|c|c|c|c|c|c|}
\hline Sample & $1967-1970$ & $71-75$ & $76-80$ & $81-85$ & $86-90$ & $91-95$ & $96-00$ & 2001-2005 \\
\hline \multirow[t]{2}{*}{ Bottom Third in Finance } & -0.58205 & -0.60036 & -0.41412 & -0.44401 & -0.2858 & -0.14351 & -0.41276 & -0.22189 \\
\hline & [0.18298] & [0.18757] & {$[0.10070]$} & [0.11799] & [0.10623] & {$[0.13066]$} & [0.16468] & [0.13544] \\
\hline \multirow[t]{2}{*}{ Middle Third in Finance } & -0.59635 & -0.47248 & -0.56554 & -0.36725 & -0.20259 & -0.17626 & 0.03301 & 0.00476 \\
\hline & {$[0.22593]$} & [0.19836] & [0.12501] & [0.12536] & [0.10422] & {$[0.13548]$} & [0.13380] & [0.11694] \\
\hline \multirow[t]{2}{*}{ Top Third in Finance } & -0.78108 & -0.63339 & -0.95786 & -0.55203 & -0.28899 & 0.09347 & -0.26708 & -0.14711 \\
\hline & {$[0.30781]$} & [0.26623] & {$[0.19315]$} & [0.16383] & {$[0.13484]$} & [0.15288] & {$[0.17358]$} & {$[0.12580]$} \\
\hline \multirow[t]{2}{*}{ Middle Third } & -0.23101 & -0.27866 & -0.37775 & -0.40952 & -0.32161 & -0.45454 & -0.33456 & -0.36635 \\
\hline & {$[0.05508]$} & {$[0.05584]$} & {$[0.03366]$} & [0.03771] & {$[0.03423]$} & {$[0.04278]$} & {$[0.04464]$} & [0.03748] \\
\hline \multirow[t]{2}{*}{ Top Third } & -0.74294 & -0.71106 & -0.78857 & -0.75884 & -0.79157 & -0.94773 & -0.74116 & -0.68784 \\
\hline & {$[0.06744]$} & [0.06835] & [0.04078] & {$[0.04364]$} & {$[0.04084]$} & {$[0.05206]$} & [0.05249] & {$[0.04305]$} \\
\hline \multirow{2}{*}{ Full Time } & -0.58853 & -0.55453 & -0.52187 & -0.4902 & -0.57371 & -0.52462 & -0.59959 & -0.61395 \\
\hline & {$[0.04989]$} & [0.05143] & {$[0.03085]$} & {$[0.03617]$} & [0.03294] & [0.04212] & {$[0.04350]$} & {$[0.03789]$} \\
\hline \multirow[t]{2}{*}{ White } & -0.24765 & -0.2891 & -0.28991 & -0.25684 & -0.24805 & -0.09657 & -0.22218 & -0.19959 \\
\hline & {$[0.06480]$} & {$[0.06529]$} & [0.03939] & {$[0.04430]$} & {$[0.04000]$} & {$[0.05083]$} & {$[0.05036]$} & {$[0.03997]$} \\
\hline \multirow[t]{2}{*}{ Male } & 0.37533 & 0.31184 & 0.35865 & 0.46078 & 0.3633 & 0.39333 & 0.33302 & 0.40178 \\
\hline & {$[0.04565]$} & [0.04539] & {$[0.02755]$} & [0.03083] & {$[0.02786]$} & {$[0.03515]$} & [0.03622] & {$[0.03057]$} \\
\hline \multirow[t]{2}{*}{ Married } & -0.24677 & -0.16369 & -0.25301 & -0.20331 & -0.22019 & -0.26551 & -0.40752 & -0.41649 \\
\hline & {$[0.04746]$} & {$[0.04747]$} & {$[0.02840]$} & {$[0.03197]$} & [0.02933] & {$[0.03707]$} & {$[0.03796]$} & [0.03193] \\
\hline \multirow[t]{2}{*}{ Urban } & 0.04582 & 0.00895 & 0.01026 & 0.04839 & 0.0555 & 0.08867 & 0.02174 & 0.02524 \\
\hline & {$[0.04448]$} & [0.04592] & [0.03029] & [0.03428] & [0.03271] & [0.04113] & [0.04210] & {$[0.03627]$} \\
\hline \multirow[t]{2}{*}{ Potential Experience } & -0.01259 & -0.01644 & -0.0197 & -0.01569 & -0.01427 & -0.01376 & -0.01079 & -0.00824 \\
\hline & {$[0.00150]$} & [0.00153] & [0.00099] & [0.00114] & [0.00109] & [0.00139] & [0.00143] & [0.00122] \\
\hline Obs & 43005 & 32038 & 86543 & 67199 & 89103 & 61296 & 71818 & 96303 \\
\hline
\end{tabular}

Notes: Logit regressions for individuals employed in the private sector at time $t$. Dependent variable is 1 if individual is unemployed at time $t+1$ (see appendix for exact definition of unemployed) and zero otherwise. Three dummies characterizing the position of the individual in the overall wage distribution (bottom, median and top third) are interacted with a dummy for the financial sector. The control group for education consists of individuals in the bottom third of the wage distribution and who work outside the financial sector. Married is a dummy variable for individuals who are married and not separated. Urban is a dummy variable for individuals who live in an MSA (Census metropolitan statistical area) in a central city (until 2003) or in a principal city (after 2004). Potential Experience is calculated as min\{age-years of school-6, age-18\}. Each column reports the estimates over a 5-year period (the first column has only 4 years). All regressions include intra-period year dummies, which are not reported. Standard errors in brackets. Data: March CPS. 
Figure 1: The Growth of the Financial Sector

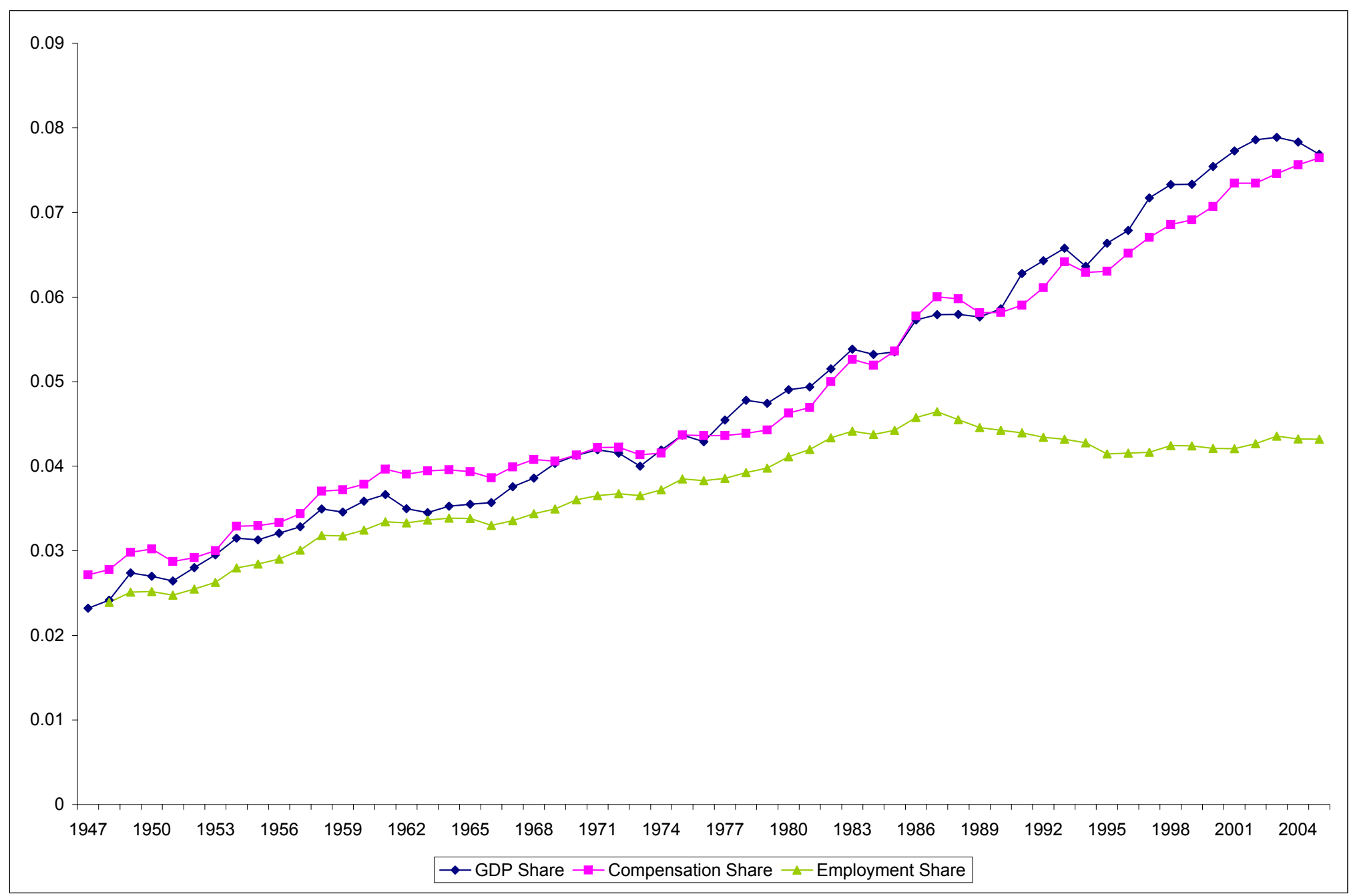

Notes: Finance includes Insurance but excludes Real Estate. Value added share is the nominal value added of the financial sector divided by the nominal GDP of the U.S. Employment includes full-time and part-time employees. Data: Annual Industrial Accounts, Bureau of Economic Analysis. 
Figure 2: Evolution of Industries

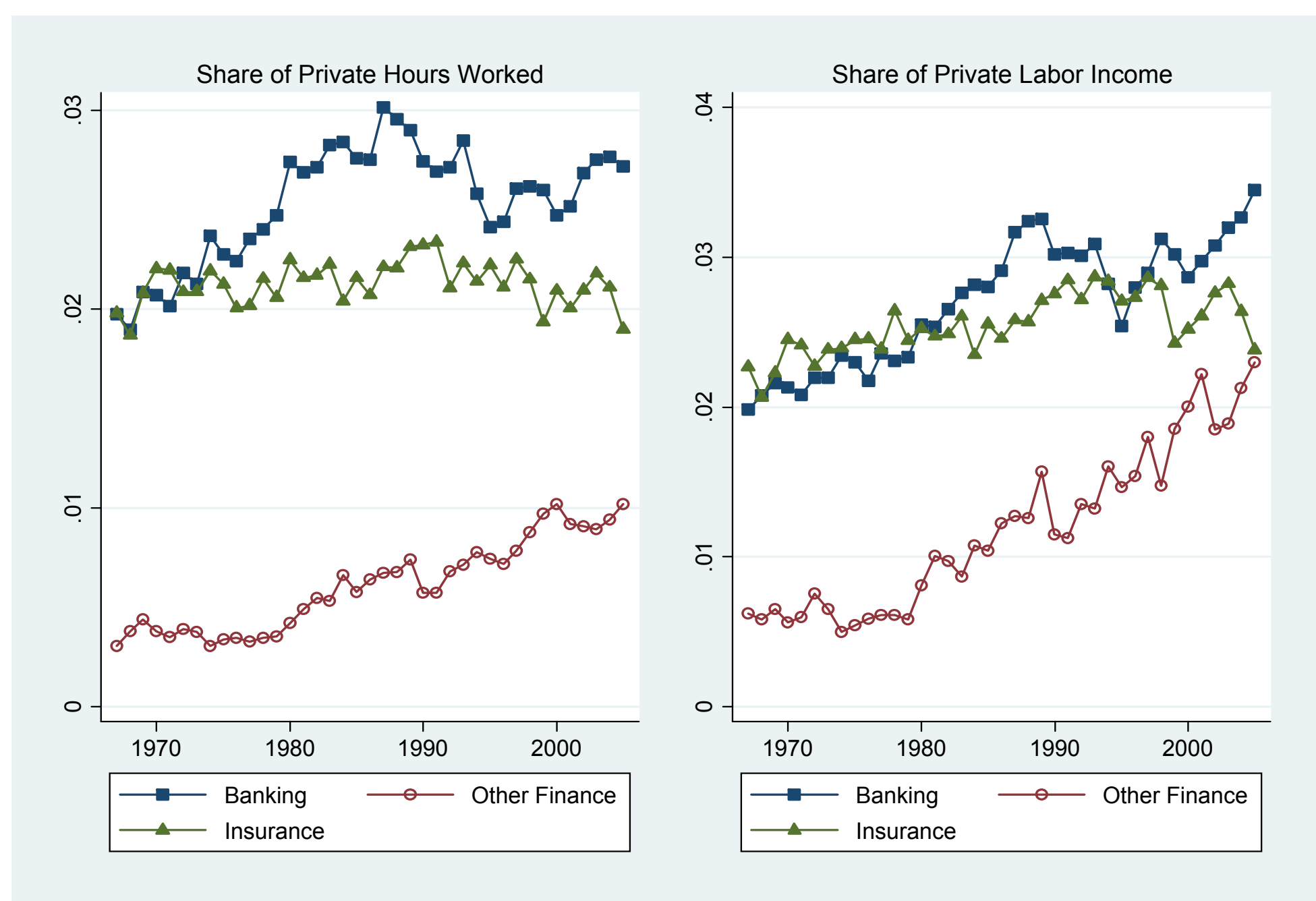

Notes: Share of Private Hours Worked is the number of hours worked in the sector divided by the total number of hours worked in the entire private sector. Share of Private Labor Income is the sum of annual wages paid to employees of the financial sector divided by the sum of annual wages in the entire private sector. Hours and wages are weighted using sampling weights. Data: March CPS 
Figure 3: Relative Wages and Education in Financial Sector

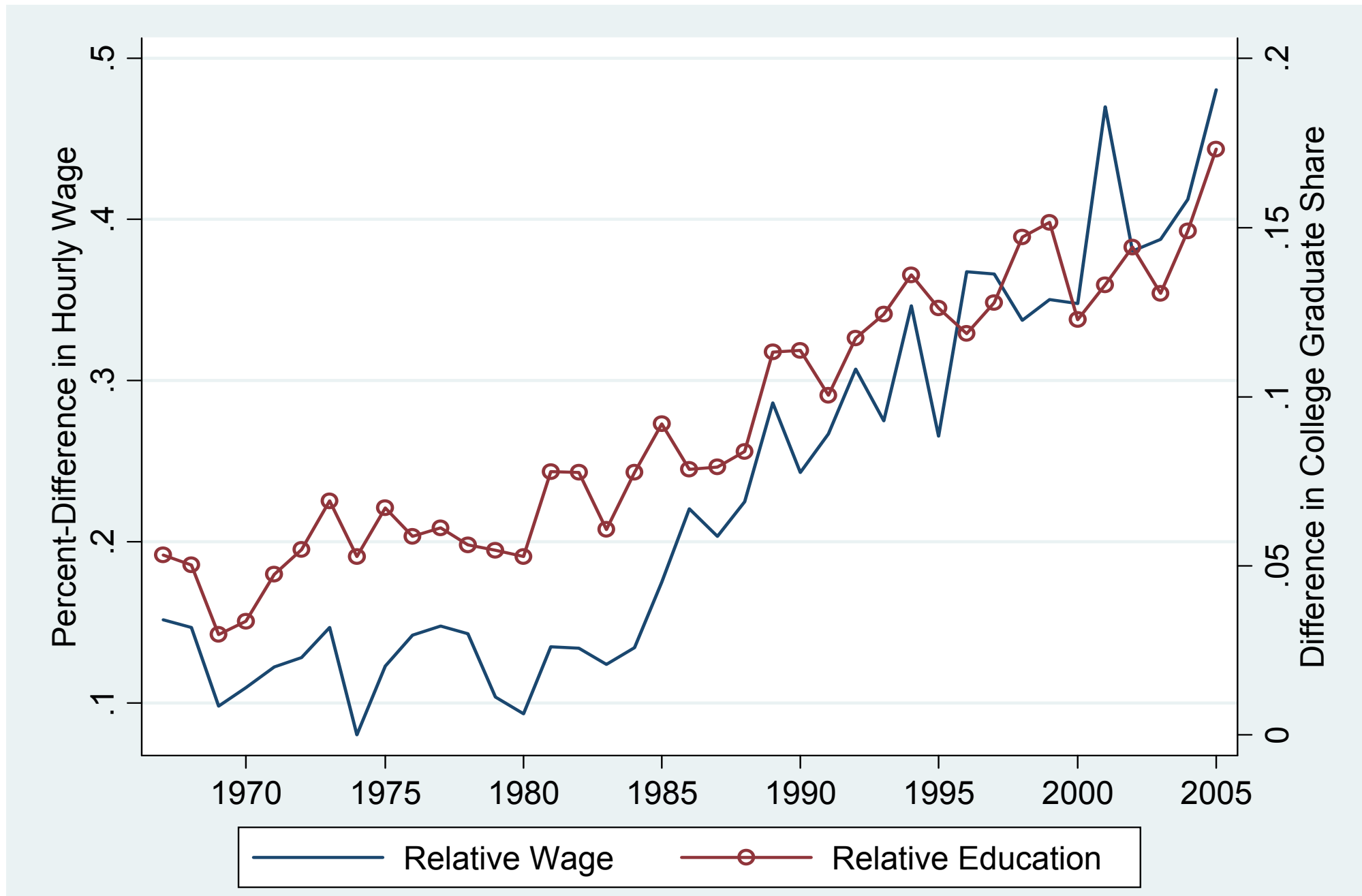

Notes: Relative Wage is the percentage difference in average hourly wages between employees in the financial sector and employees in the rest of the (private) economy. Relative Education is the share of hours worked in the financial sector accounted for by employees with at least a college degree, minus the corresponding share in the rest of the private sector. Data: March CPS. 
Figure 4: College Graduates and Education Intensity

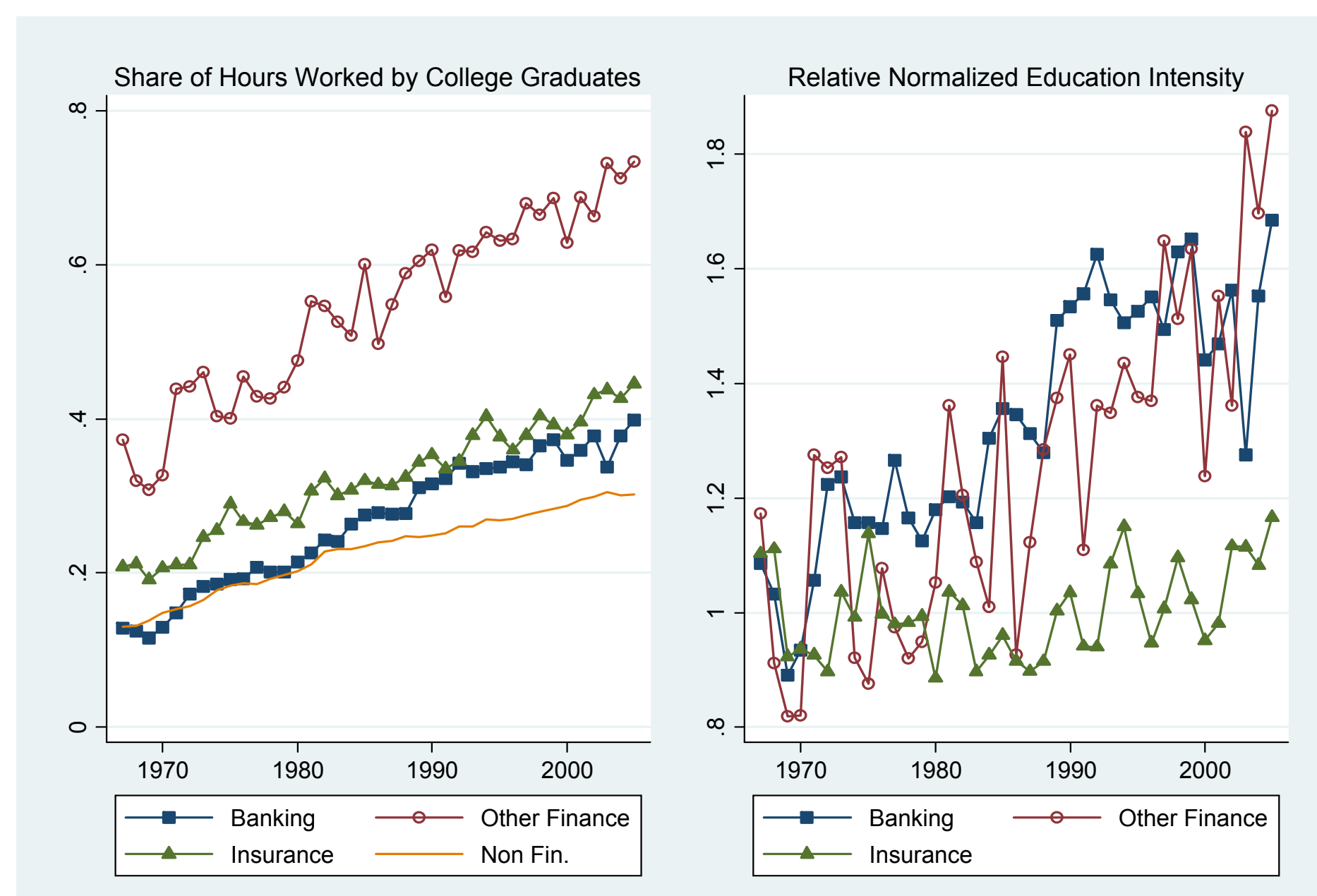

Notes: Share of Hours Worked by College Graduates is the share of hours worked in the sector accounted for by employees with at least a college degree. Relative Normalized Education Intensity is the ratio of high skilled hours over low skilled hours in the particular sector, divided by the same ratio in the rest of the private sector. The measure is normalized so that it has a mean of one over the first five years of the sample. Hours and wages are weighted using sampling weights. Data: March CPS. 
Figure 5: Hour-Shares of Occupations in the Financial Sector

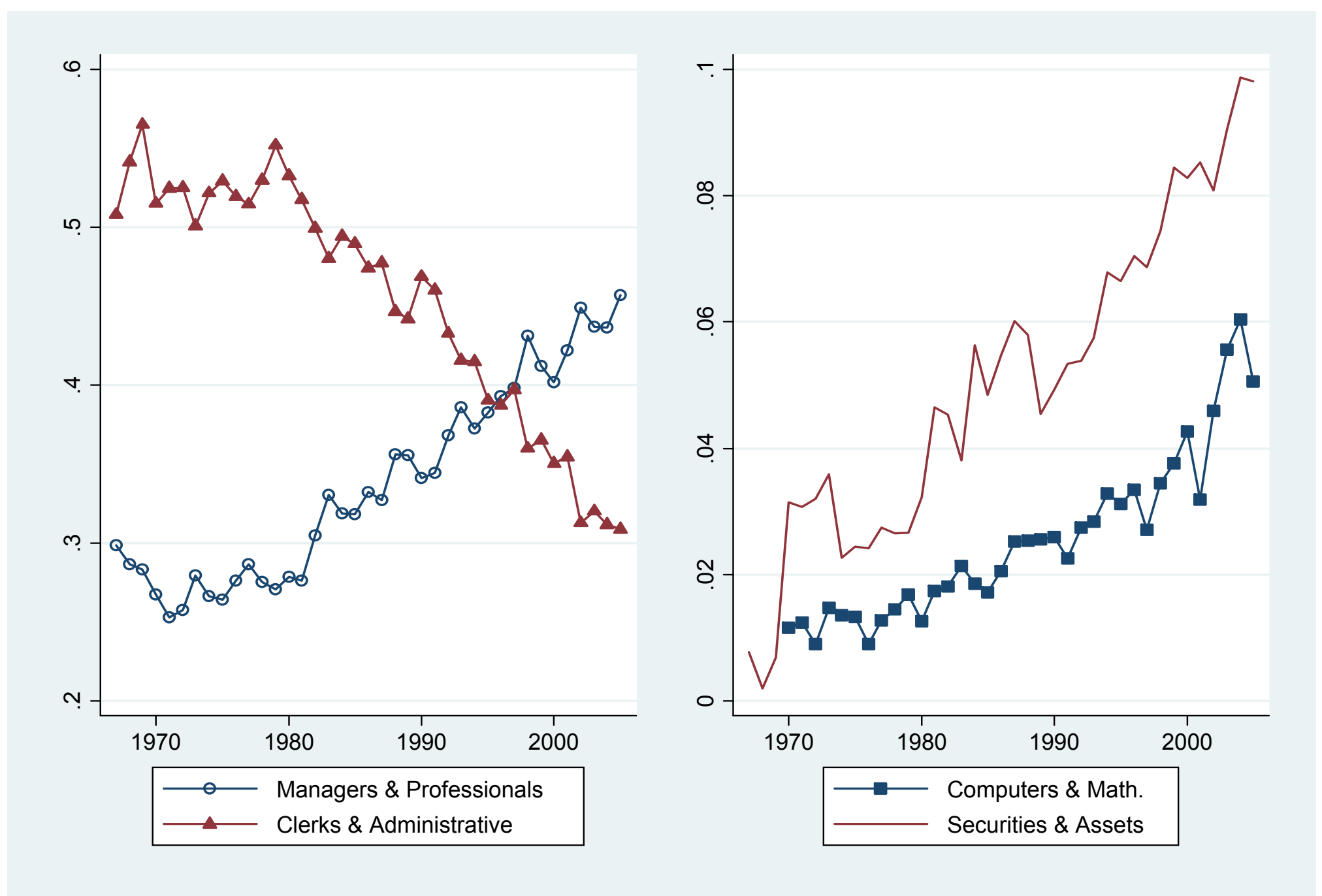

Notes: Hours worked by employees in a given occupation divided by total hours worked in the financial sector. Hours and wages are weighted using sampling weights. Data: March CPS. 
Figure 6: Annual Income of Engineers and Financiers
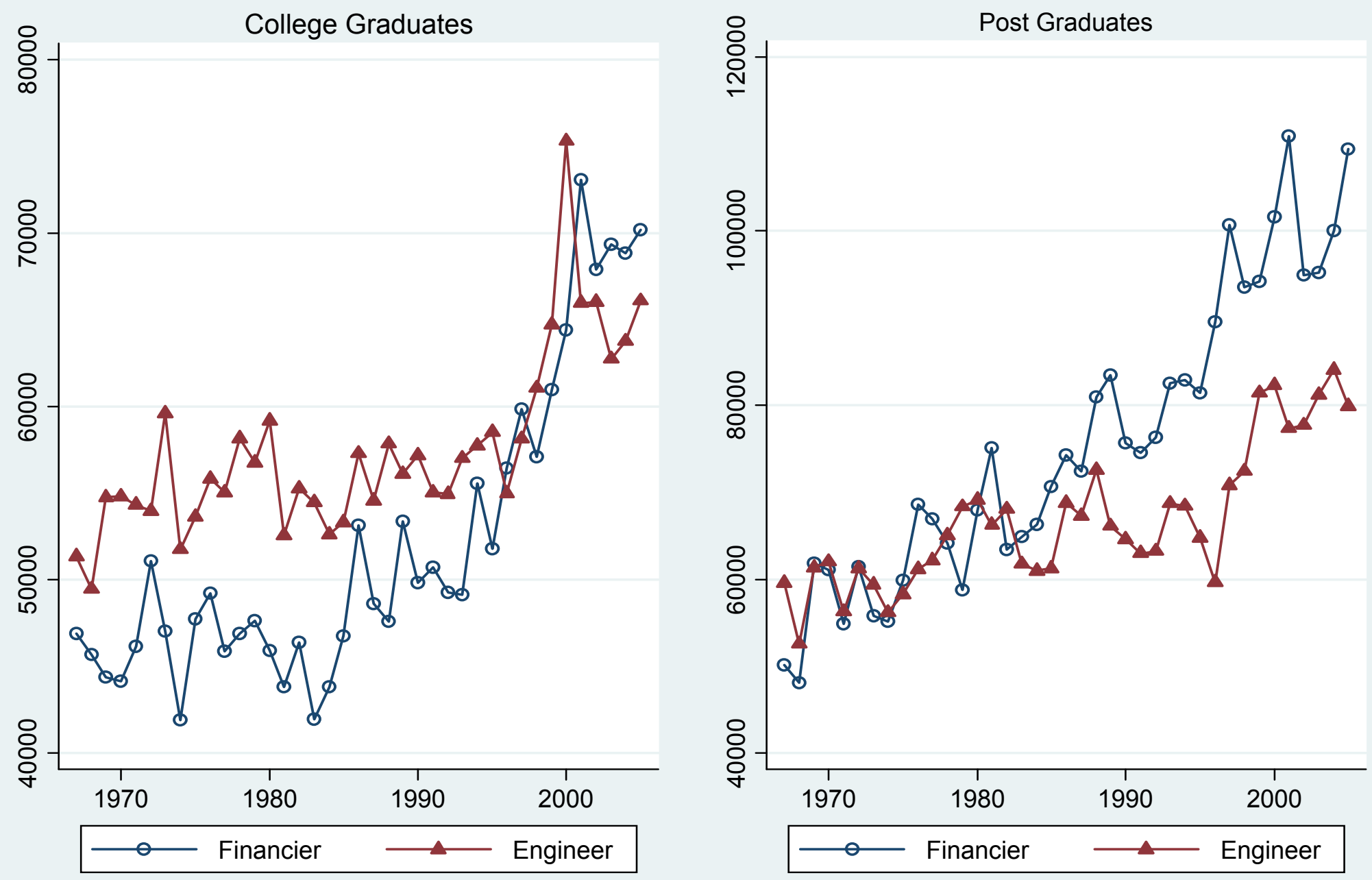

Notes: All wages are in 2001 U.S. dollars and are weighted using sampling weights. Data: March CPS. 
Figure 7: Finance Wage Premium, with and without Education Controls

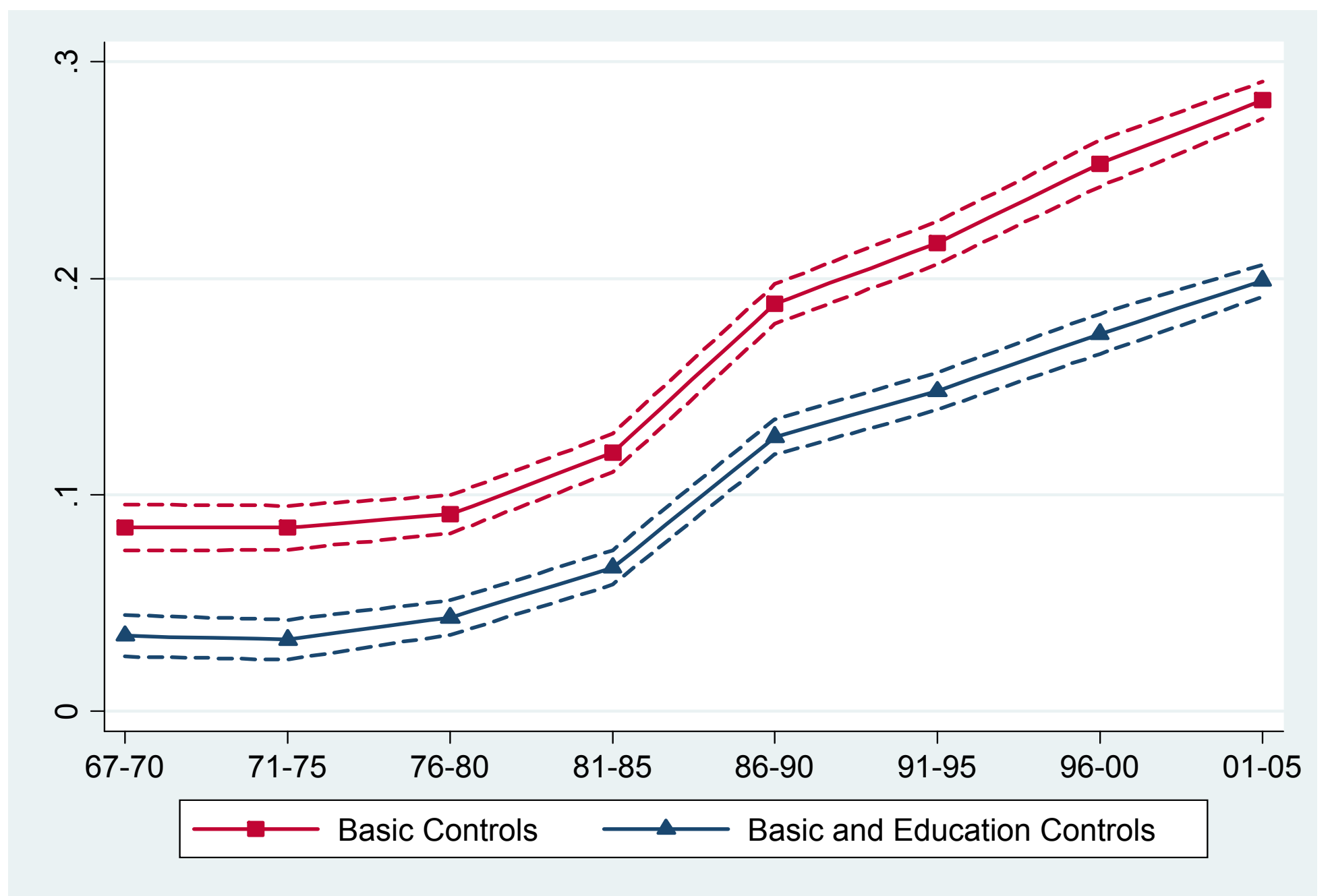

Notes: Coefficient of Finance dummy and $95 \%$ confidence intervals from regressions of log annual wages over individual characteristics. Basic controls include race, sex, marital status, urban residence, potential experience and its square. Education controls are dummies for education groups: 12 years of education, 13 to 15 years, 16 to 17 years, and 18 years or more. Data: March CPS. 
Figure 8: Wage Premia in Finance Industries, Controlling for Education

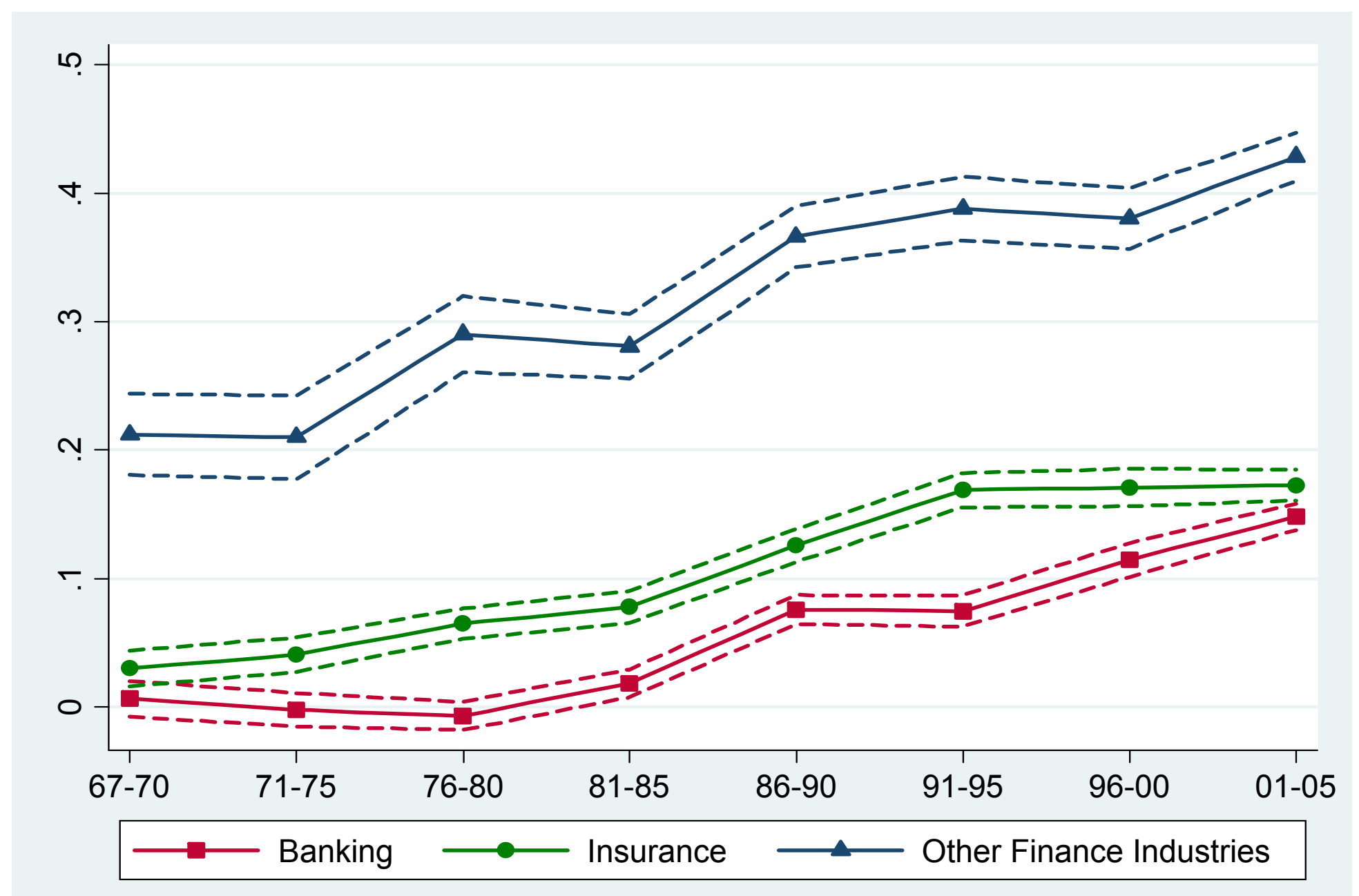

Notes: Coefficients and $95 \%$ confidence intervals for sector dummies in regression of log annual wages over individual characteristics. Controls include race, sex, marital status, urban residence, potential experience and its square. Education controls are dummies for education groups: 12 years of education, 13 to 15 years, 16 to 17 years, and 18 years or more. Data: March CPS. 
Figure 9: Wage Premia in Finance, by Education Groups

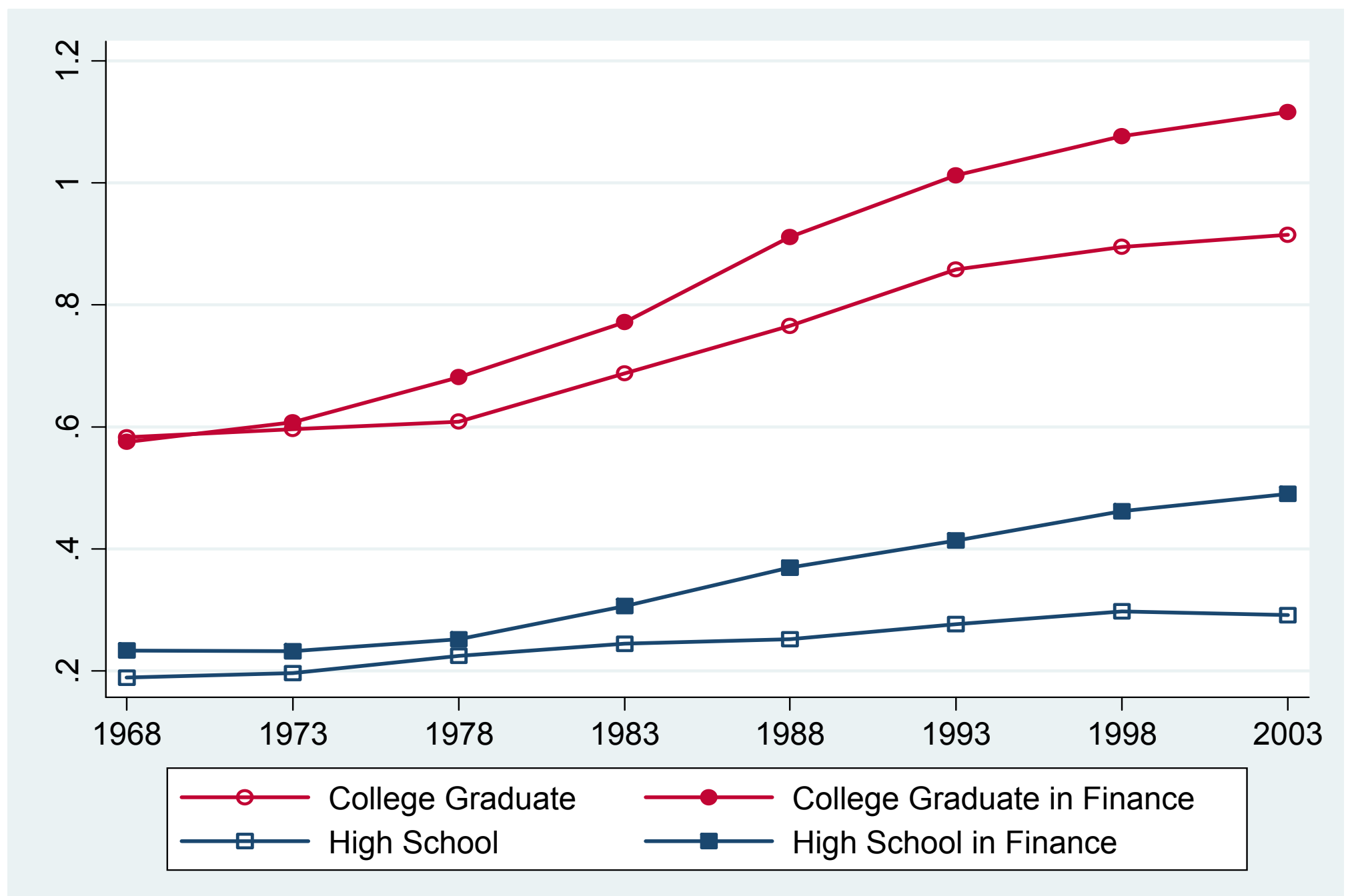

Notes: Coefficients of dummies interacted with education, from regressions of annual log wage on individual characteristics, Controls include race, sex, marital status, urban residence, potential experience and its square. Data: March CPS. 
Figure 10: Relative Unemployment Risk in Financial Sector

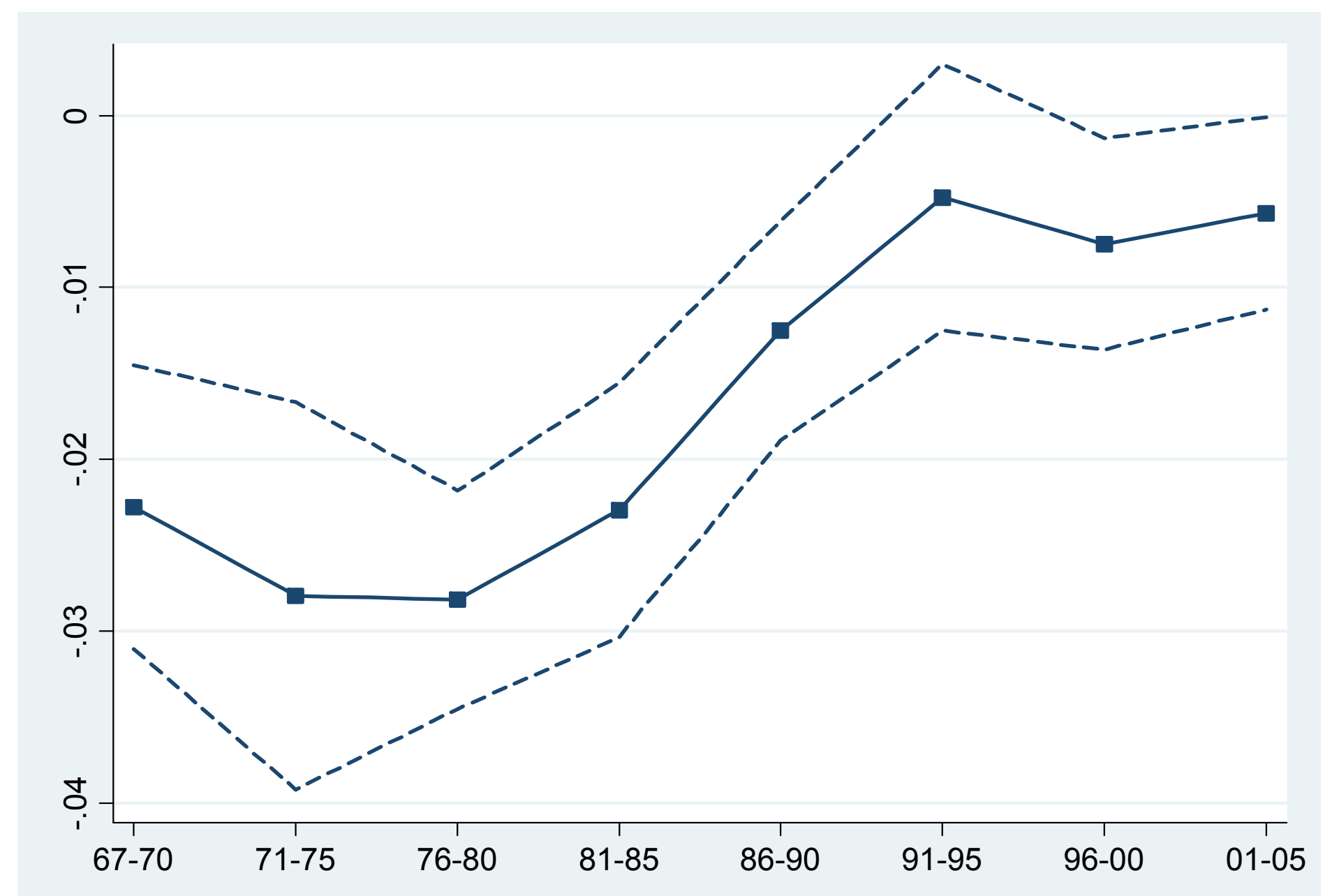

Notes: Coefficients and $95 \%$ confidence intervals of Finance dummy in logit regression of transition from Employment to Unemployment. Controls include current log wage, race, sex, marital status, urban residence, potential experience and its square. Education controls are dummies for education groups: 12 years of education, 13 to 15 years, 16 to 17 years, and 18 years or more. Data: March CPS. 
Figure 11: Relative Unemployment Risk in Financial Sector, sorted by Current Wage

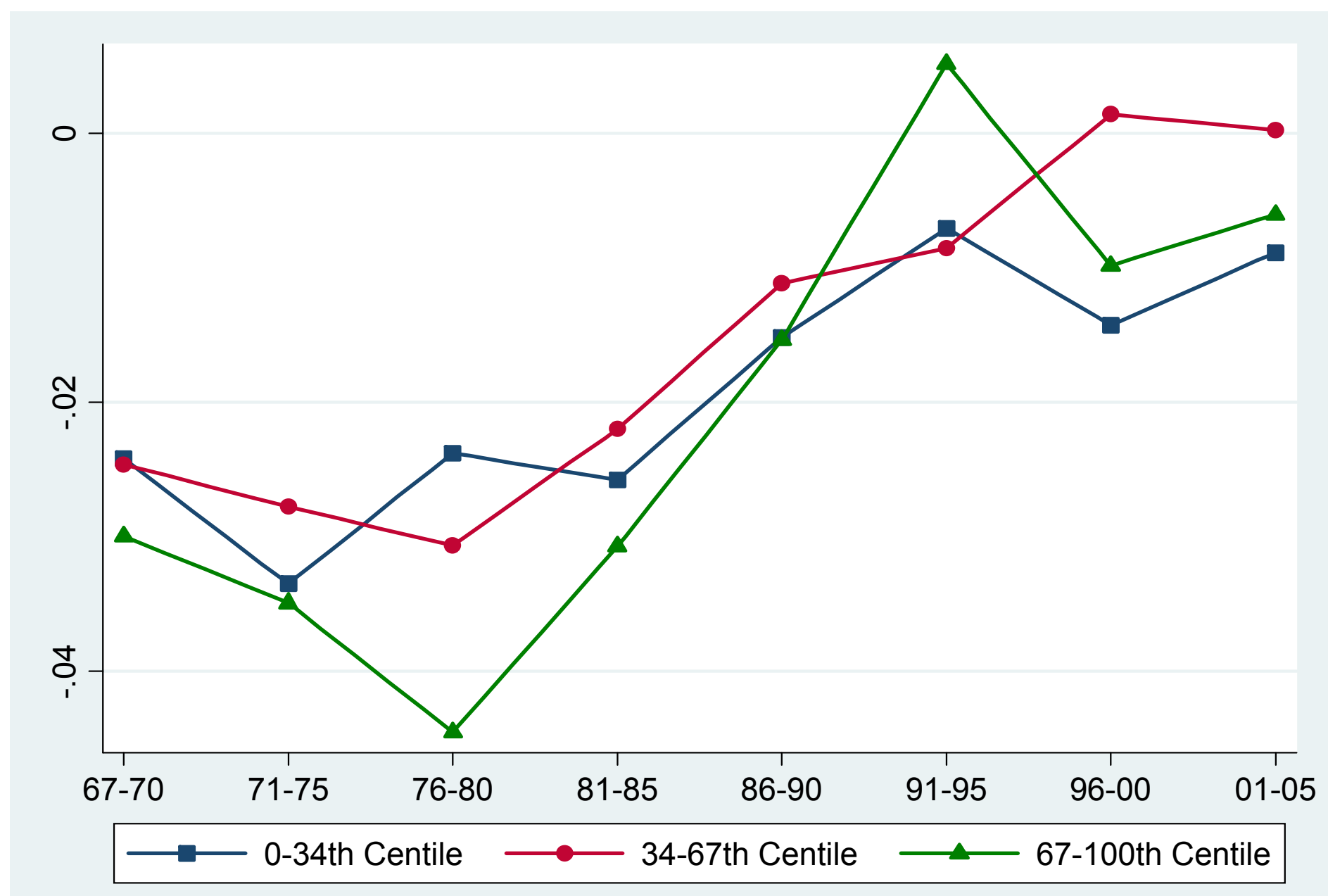

Notes: Coefficients for position in the wage distribution in logit regression of transition from employment to unemployment. Controls include current log wage, race, sex, marital status, urban residence, potential experience and its square, as well as the position of the individual in the current income distribution: bottom third, middle third or top third. Data: March CPS. 